This PDF is a selection from a published volume from the National Bureau of Economic Research

Volume Title: Housing and Mortgage Markets in Historical Perspective

Volume Author/Editor: Eugene N. White, Kenneth Snowden, and Price Fishback, editors

Volume Publisher: University of Chicago Press

Volume ISBN: 0-226-07384-X (cloth); 978-0-226-07384-2 (cloth); 978-0-226-09328-4 (EISBN)

Volume URL: http://www.nber.org/books/fish12-2

Conference Date: September 23-24, 2011

Publication Date: July 2014

Chapter Title: Lessons from the Great American Real Estate Boom and Bust of the 1920s

Chapter Author(s): Eugene N. White

Chapter URL: http://www.nber.org/chapters/c12797

Chapter pages in book: (p. 115 - 158) 


\title{
Lessons from the Great American Real Estate Boom and Bust of the 1920s
}

\author{
Eugene N. White
}

You can have any kind of a home you want to; you can even get stucco. Oh, how you can get stuck-oh!

—Groucho Marx, The Cocoanuts (1929) ${ }^{1}$

Although apparently dwarfed by the magnitude of the recent events, real estate booms and busts were not unknown in the past. Huge swings in real estate prices and construction occurred at long intervals, but they did not always spell disaster for the financial sector. Thus, an important question for today is not why there was a boom, but why its consequences were so severe for banks and other intermediaries compared to previous episodes. The 1920 s, the 1980s, and the first years of the twenty-first century constitute the three great real estate events of the last one hundred years. Focusing on the 1920s is useful; for although many analysts of the current crisis maintain that its dimensions are unique, the overlooked twenties has surprisingly similar characteristics yet there was no banking crisis.

Complicating the analysis of current events are the many potential factors given for the boom. A short list of major contenders would include: (a) the

Eugene N. White is Distinguished Professor of Economics at Rutgers University and a research associate of the National Bureau of Economic Research.

For their comments and suggestions, I would especially like to thank Lee Alston, George Berry, Michael Bordo, Price Fishback, Richard Grossman, Kris Mitchener, Carolyn Moehling, John Landon-Lane, Hugh Rockoff, Kenneth Snowden, Peter Temin, and the participants of seminars at the Bank of England, Columbia University, the Federal Reserve Bank of Philadelphia, the Federal Reserve Bank of St. Louis, the Free University of Brussels, the German Historical Institute (Washington, DC), the Harvard Business School, Université Paris X Nanterre, the NBER Summer Institute, Rutgers University, the Universitat Pompeu Fabra, the University of Oslo, and the XVth World Economic History Conference, Utrecht. For acknowledgments, sources of research support, and disclosure of the author's material financial relationships, if any, please see http://www.nber.org/chapters/c12797.ack.

1. In popular culture, the 1920 s real estate boom is remembered in the Marx Brothers' 1925 musical The Cocoanuts, which became the 1929 movie by the same name. In one scene in the film, Groucho Marx is an auctioneer of Florida land of questionable value. 
Federal Reserve's excessively easy monetary policy; (b) the "Greenspan put"; (c) the failure of bank supervision; (d) moral hazard from "too big to fail" and deposit insurance; (e) deregulation of banking (notably the end of the Glass-Steagall Act); (f) the failure of rating agencies; (g) the excessive growth of Fannie Mae and Freddie Mac; (h) legislation promoting affordable housing; (i) international imbalances, notably high savings rates in China and East Asia; (j) unregulated derivatives markets; (k) greedy/predatory lenders; and (1) greedy/ignorant borrowers. These factors are used to structure my inquiry into the real estate boom of the twenties, which displayed many similar characteristics, including surging housing starts, strong regional elements, and financial innovation. Most elements blamed for the current crisis were present: weak supervision, securitization, and a fall in lending standards. The relatively more extreme character of these factors in the early twentyfirst century, emphasizes the absence of policy and regulatory incentives for banks in the 1920s to take on more risk and increase their leverage.

Two monetary factors, often cited as central to the current crisis, were present in the 1920s. First, there was a "Greenspan put" that reduced money market volatility and the likelihood of a panic. Secondly, there were low interest rates that potentially provided fuel for the surge in building. However, alternative monetary policies, as defined by Taylor rules, would not have been enough to halt the boom. Whatever impetus came from these and other factors, banks were sufficiently well-capitalized and remained prudent lenders. Consequently, a drop in residential real estate prices constituted little threat to their solvency; and the storm passed without bringing down the financial system.

\subsection{Why Was the 1920s Real Estate Bubble Forgotten?}

Few economists have taken note of this early real estate bubble, perhaps because it was followed and obscured by the Great Depression. However, the wild boom in Florida did draw Galbraith's attention in The Great Crash (1954). He saw the rise and fall of Florida real estate as a classic speculative bubble: "The Florida boom was the first indication of the mood of the twenties and the conviction that God intended the American middle class to be rich." ${ }^{2}$ Conceding that there were elements of substance, Galbraith viewed it as based on the self-delusion that the Florida swamps would be wonderful residential real estate. In spite of the fact that he saw the Florida land boom as a harbinger of the stock market bubble, Galbraith failed to recognize that it was a nationwide event. ${ }^{3}$ How well the real estate boom

2. Galbraith $(1954,6)$.

3. In his stylized outline of financial crises, Kindleberger (1978) identifies a land boom, cresting in 1925, as preceding the stock market boom of 1928 to 1929, but does not provide further commentary. 
of the 1920s was forgotten by economists is revealed in the first edition of Shiller's Irrational Exuberance (2000), where it is not even mentioned. Only in his 2007 presidential address to the Eastern Economic Association did Shiller shift his focus from equity to real estate markets. Yet Florida rates only a brief mention, and he describes the collapse as the result of a change in investor psychology prompted by the surprise increase in the supply of properties.

The more general collapse of residential investment and housing prices was, however, recognized by contemporaries. For example, Simpson (1933) found that there was an excessive expansion of residential construction in 1920s Chicago, abetted by an unholy alliance of real estate promoters, banks, and local politicians. In Cook County, he claimed that there were 151,000 improved lots and 335,000 vacant lots in the bust year of 1928, estimating it would take until 1960 to sell these properties based on his projection of future population growth. He considered Chicago to be an important example of the bubble, although Florida was the most conspicuous. Yet, beyond bewailing current conditions, Simpson provided few statistics and confounded the problems of the real estate bust with the Great Depression.

Early post-World War II research was focused on the recovery from the Depression. Morton (1956) and Grebler, Blank, and Winnick (1956) and others did not isolate the collapse of the 1920s from the Great Depression and treated it as one blur. Their implicit belief was that the New Deal reforms of banking and mortgage finance resolved most of the problems with real estate in the 1930s - thus the boom and bust of 1920s did not require special attention as a separate issue.

The only modern Great Depression study where there was a suggestion that the real estate collapse in the mid-1920s played a role in the Depression's onset was Temin's Did Monetary Forces Cause the Great Depression? (1976). Temin found that aggregate investment began to decline autonomously before 1929 and that the driving factor was the fall in construction after 1926, although he did not tie this to the demise of the residential housing boom. Two histories (Vickers 1994; Frazer and Guthrie 1995) provide details on the Florida boom but treat it as an isolated phenomenon. In a more recent national study, Field (1992) saw the general building boom of the 1920s as creating major problems for the economy. He identified a residential boom peaking in 1925, "a smaller orgy of apartment building" cresting in 1927, and a central business district upswing continuing through 1929. Yet, his emphasis was not on a bubble with excessive aggregate investment but on the consequences of unplanned and unregulated development that later blocked the recovery of existing subdivisions because it raised the transaction costs associated with titles and tax liens. Given this general amnesia, the first task of this chapter is to describe the dimensions of the national residential real estate boom that swept the country. 


\subsection{Measuring the Residential Housing Boom of the 1920s}

Like the current boom and bust, the housing bubble that peaked in the mid-1920s primarily involved residential housing. In a decade of almost steady growth, the behavior of residential construction stands out among other macroeconomic aggregates, peaking in the middle of the decade and collapsing well in advance of the Great Depression. Figure 4.1 plots residential housing starts for the boom of the 1920s and the contemporary period.

The early series begins in 1889 , the first year for when there is national data; it attains a peak in 1925 that was not surpassed until 1949. The contemporary series is noticeably more volatile, particularly in the 1970s and 1980s, when swings in inflation and interest rates buffeted the housing markets. In contrast, price stability of the gold standard period kept mortgage rates in Manhattan between 5 and 6 percent for the whole era, except for World War I. ${ }^{4}$ As the population of the country was considerably smaller ninety years ago, the level of housing starts was lower, but the run-up during the booms is of the same magnitude. If 1920 and 2000 are considered baseline years, the boom of the twenties added 2.6 million units while the boom of the first decade of the twenty-first century added 1.3 million units, with starts 690,000 and 500,000 higher in the final years relative to the initial years.

Not all construction flourished during the boom of the 1920s, and residential housing dominated other types of construction expenditures. Whereas business construction, "other private construction," in figure 4.2, had been the largest component of construction in the pre-World War I era, residential construction surged ahead, more than doubling in importance. Business construction returned to prewar levels in the twenties, but the value of residential construction greatly exceeded its 1914 levels.

The subsequent stock market boom of 1928-1929 offers another useful comparison for measuring the magnitude of this surge in residential housing. Figure 4.3 depicts the value of new residential construction and the value of new stock issues, revealing the double real estate-stock market bubble of the 1920s, another parallel to the end-of-century double dotcomreal estate boom, but with the order reversed. Housing market run-ups are typically slower and smoother than in equity markets, but both experienced rapid upswings and quick declines. The peak in housing was reached when there was almost $\$ 10$ billion in new residential construction for the two years 1925 and 1926, equaling the $\$ 10$ billion absorbed by new securities issues in 1928 and 1929.

The thorniest problem encountered in measuring the real estate boom of the 1920s is the absence of an adequate housing price index. As is well

4. Grebler, Blank, and Winnick (1956, table 0-1). 


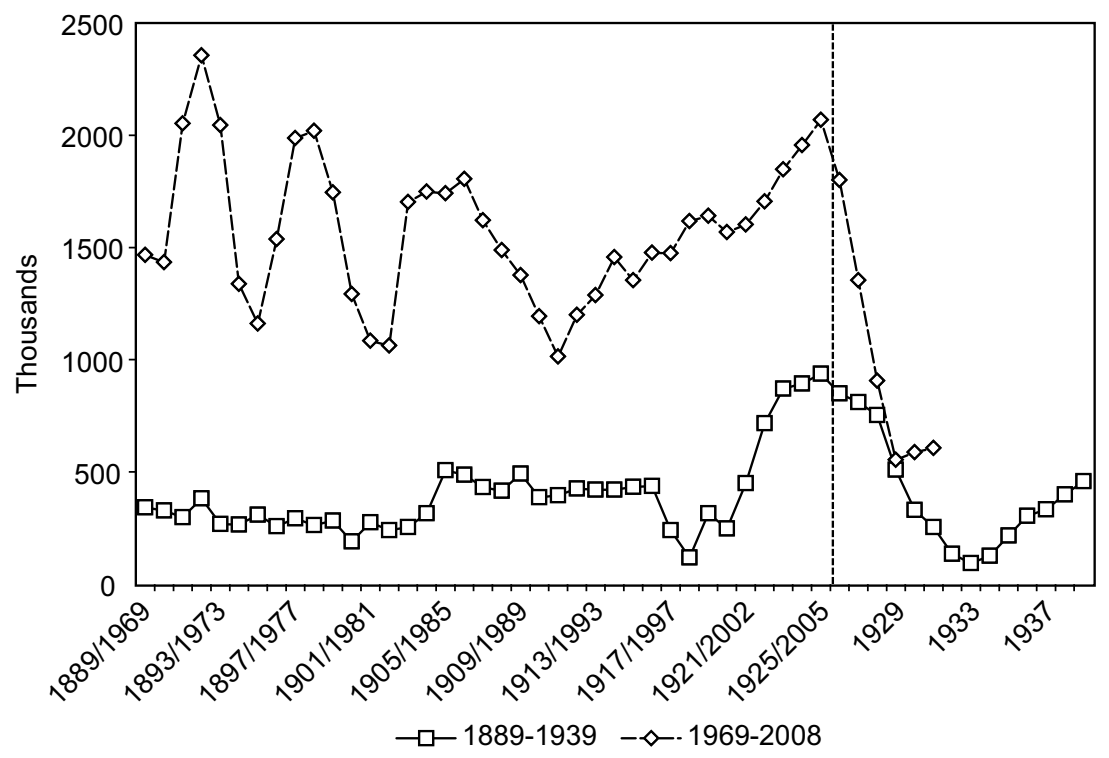

Fig. 4.1 Residential housing starts, 1889-1939 versus 1969-2011

Sources: Carter et al. (2006, series Dc510); Economic Report of the President (2009, table B-56).

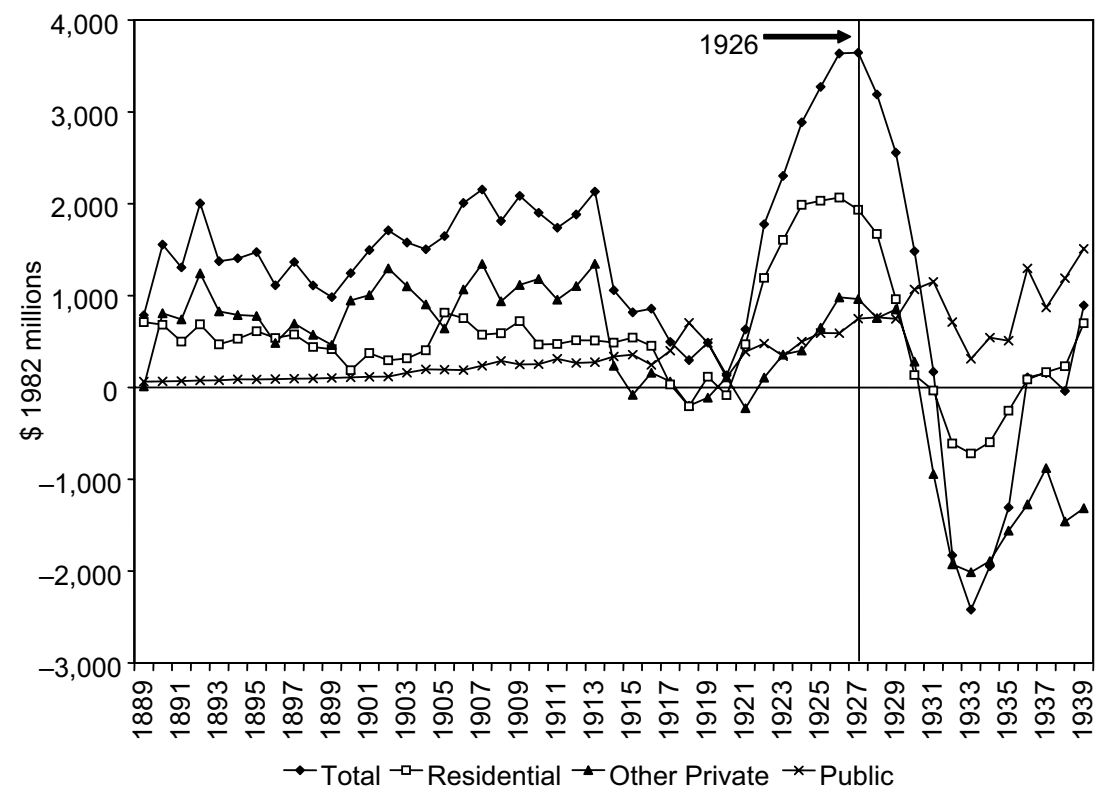

Fig. 4.2 Net real construction expenditures, 1889-1939

Source: Carter et al. (2006, series Dc87-90, series Cc66). 


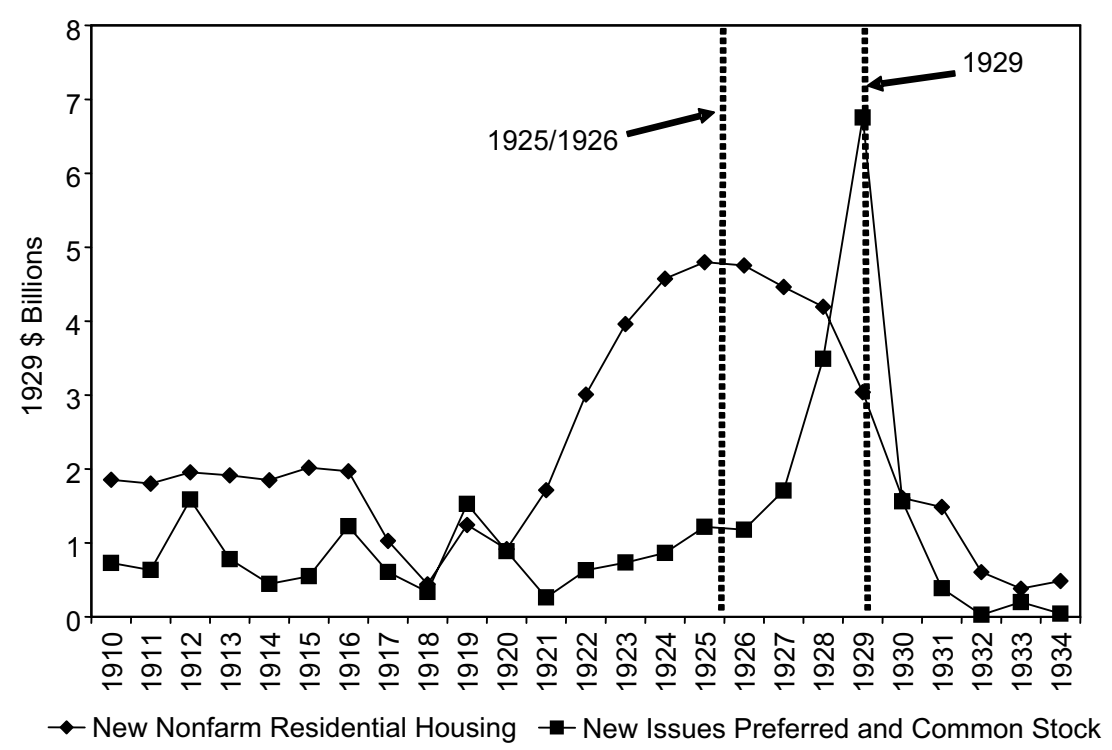

Fig. 4.3 Real new housing and new stocks issues, 1910-1934

Sources: Carter et al. (2006, series Cj835 and 836, new residential construction, series Dc257 for 1915-1939); and Grebler, Blank, and Winnick (1956, table B-5).

known, even contemporary housing price indices vary considerably depending on their construction. ${ }^{5}$ Figures 4.4 and 4.5 report two different indices, which may point to upper and lower limits on the size of the bubble. Figure 4.4 examines three booms using the Case-Shiller real home price index (Shiller, www.econ.yale.edu/ shiller/). Setting 1920, 1984, and 2001 (five years before the price peaks) as the base years for three separate indices, the relative magnitude of each boom can be appreciated. In the current cycle, prices jumped 50 percent in five years to reach their peak in 2006. By this index, the 1920s does not appear to be as big as the current boom, but it was certainly as large as the boom in the 1980 s with national housing prices rising 20 percent before declining over 10 percent. While modest by comparison to today, the eighties were disastrous for real estate in the Northeast, Texas, and California, contributing to the demise of many banks.

Unfortunately, the index presented by Shiller appears to have a strong downward bias for the 1920s. Grafted on to the Case-Shiller index, these data for earlier years are very different in origin. The source of this preDepression national index is Grebler, Blank, and Winnick (1956). This series is based on a 1934 survey of owners in twenty-two cities who were asked what the current value of their home was and what it cost in the year of acquisition. There were two problems that the authors were not able to 


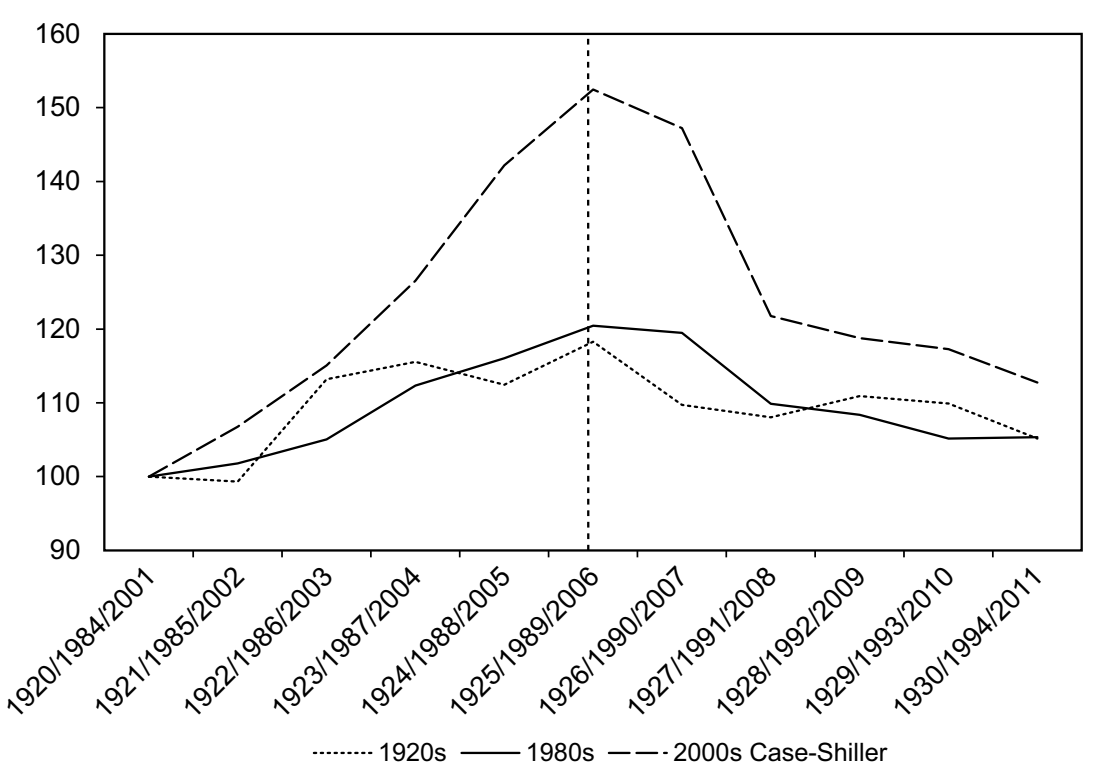

Fig. 4.4 The Case-Shiller index of real estate prices, 1920-1930, 1984-1994, 2000-2011

Source: Robert Shiller, www.econ.yale.edu/ shiller/.

address. First, the year-to-year volatility increases dramatically for the early years of the index, a feature that does not match the smooth movement of contemporary indices. This phenomenon may be attributable to the smaller and smaller number of observations in each year for houses that were purchased twenty, thirty, or forty years before 1934. Secondly, if foreclosures or abandonment of property were more common for owners who had bought late in the boom at high prices, the peak of the boom would be underestimated. The size of this potential downward bias is difficult to assess in the absence of sufficient additional national or regional data.

Florida, which may have had the biggest boom and crash in the twenties, has no housing prices index. One of the few available local series is the median asking price of single family homes in Washington, DC, which was not considered part of the boom regions. ${ }^{6}$ Real prices of these homes rose 38 percent from 1920 to the peak, dropping by nearly 10 percent before $1929 .{ }^{7}$ A rise of this magnitude alone would place the twenties as the second greatest real estate boom of the last one hundred years.

A superior hedonic real estate price index for Manhattan was recently

6. Carter et al. (2006, series Dc828).

7. The only other indexes are three-year moving averages for Cleveland and Seattle, while this averaging would tend to reduce the peaks, the Cleveland index still climbed 30 percent and the Seattle index 16 percent. (Grebler, Blank, and Winnick 1956, table C-2). 


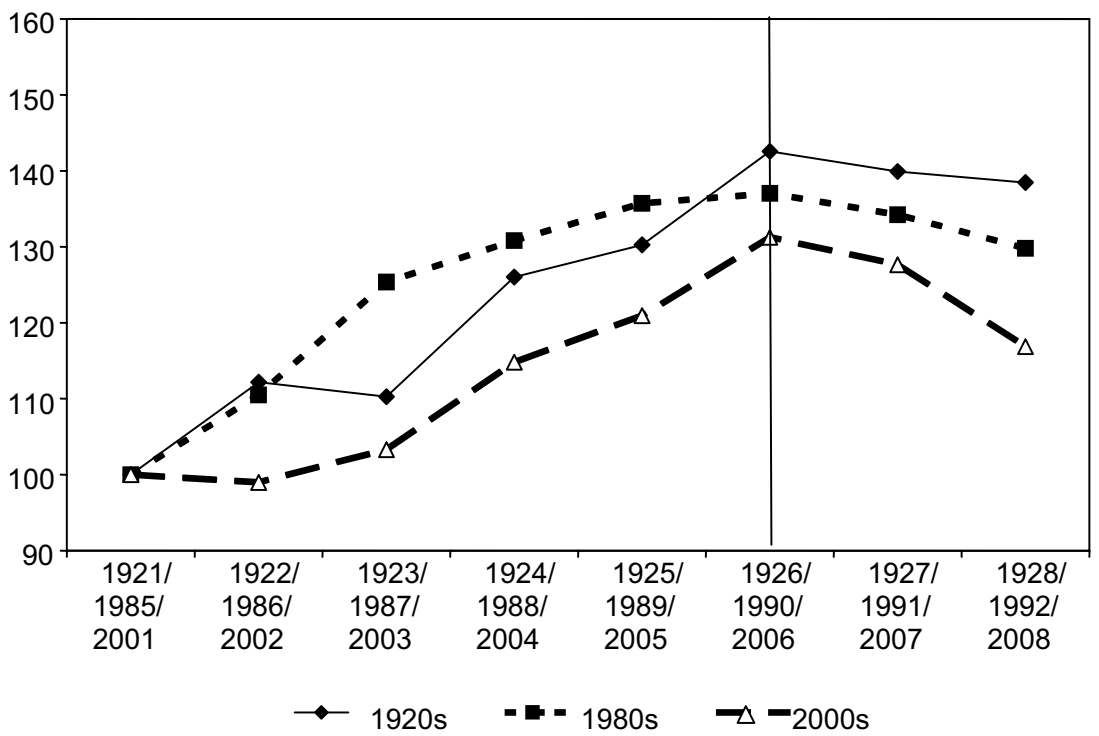

Fig. 4.5 Indices of the real value of a newly constructed house

Sources: Carter et al. (2006, series Dc257, value of new housing units, and series Dc520, number of new housing units started); Economic Report of the President (2009, table B-55, value of new residential housing units, and table B-56, new housing units started).

Note: All housing values are converted into real values using the Consumer Price Index. The value of a newly constructed house is equal to the value of new housing units divided by the number of new housing starts.

developed by Nicholas and Scherbina (2011) for 1920 to 1939. For this critical market, prices rose 54 percent between the fourth quarter of 1922 when the postwar recession ended and the second quarter of 1926, the acknowledged peak, before falling 28 percent to a low point in the second quarter of 1928. Their index also throws some light on real estate's potential path of recovery, had the Great Depression not hit the market a second time. By the third quarter of 1929 , the market had fully recovered, probably benefitting from the stock market boom on Wall Street.

Figure 4.5 shows an index for the value of newly constructed homes that is comparable across all three booms. The real value of a newly constructed house is obtained by dividing the real value of all new housing units by the number of new housing starts. By this measure, the three booms enjoyed rises of 43 percent, 37 percent, and 31 percent during the five years before the peaks in 1926, 1990, and 2006. The most recent boom is smaller here than when measured by the Case-Shiller index because it focuses on new construction; and there was a greater rise in price of existing homes in established urban areas where urban amenities and constraints on development contributed to the boom (Glaeser, Gyourko, and Saks 2005). Combined with the regional real estate prices and the surge in starts, this evidence 
reveals that the boom was not confined to Florida. The Case-Shiller index appears to seriously underestimate its magnitude and the additional data suggest that the 1920s boom rivaled the early twenty-first century boom in some dimensions.

\subsection{A Post-World War I Catch-Up?}

The underlying macroeconomic conditions for the 1920s and the early twenty-first century also share some common characteristics. ${ }^{8}$ Unemployment was low and growth was good. Likewise there had been a reduction in inflation. The great moderation in inflation after World War I, when the Federal Reserve took an activist role, attempting to lean against the prevailing macroeconomic winds, suggests that its role in the housing market requires close inspection. Just as critics today have blamed the Fed for firing up the boom, the Fed of the twenties may have contributed to the earlier jump in real estate prices if it had an excessively easy monetary policy or increased risk taking by reducing the fear of a panic. Yet, before turning to the role of the Fed, there are two other fundamentals that need to be accounted for: international imbalances and the post-World War I recovery of residential construction.

The enormous financing needs of World War I crowded out nonessential investment and consumption as resources were transferred to the government. Repressed demand helped to fuel the postwar boom in goods and inventories, but demand for housing was also constrained. ${ }^{9}$ To examine the possibility that the upsurge in home construction in the mid-1920s was only a catch-up, I provide some forecasts of what would have happened if World War I had not occurred. After first differencing to ensure the stationarity of the variables, I regressed housing starts and the real value of construction on real GDP, population, and the Manhattan mortgage rate for the years 1889 to $1914 .{ }^{10}$ The exercise is similar to Taylor's (2009) counterfactual analysis for the recent period.

The actual and predicted out-of-sample values for housing starts and the value of new construction are plotted in figures 4.6 and 4.7. The results diminish substantially the appearance of a bubble in the aggregate data. Housing starts and the value of new construction would have followed slow-

8. A factor commonly cited as a cause of the recent real estate boom is international imbalances, propelled by high savings rates in China and elsewhere in Asia that have led to the purchase of US government and agency securities. The opposite environment prevailed in the 1920s, as the United States had just switched from being a major net debtor to a major net lender. Whereas in 1908 foreign investments of $\$ 6.4$ billion far exceeded the $\$ 2.5$ billion of US investments abroad, by 1924 these had swung to $\$ 3.9$ billion and $\$ 15.1$ billion, respectively. This accelerating flow of American funds abroad was not sufficient to contain the boom, though it may have slowed it down.

9. For details on World War I finance, see Edelstein (2000) and Rockoff (2012)

10. The series are from Carter et al. (2006, series Dc510, Dc522), and Grebler, Blank, and Winnick (1956, table O-1). 


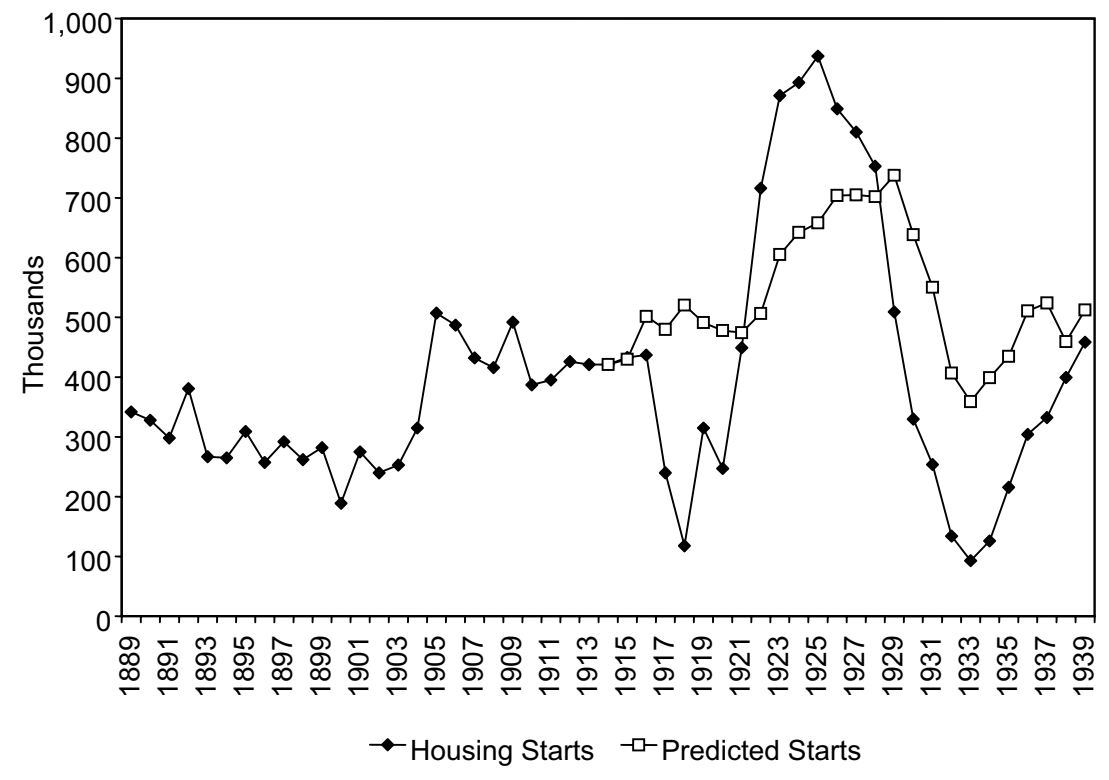

Fig. 4.6 Actual and forecast residential housing starts, 1889-1939

Source: Carter et al. (2006, series Dc510) and the text.

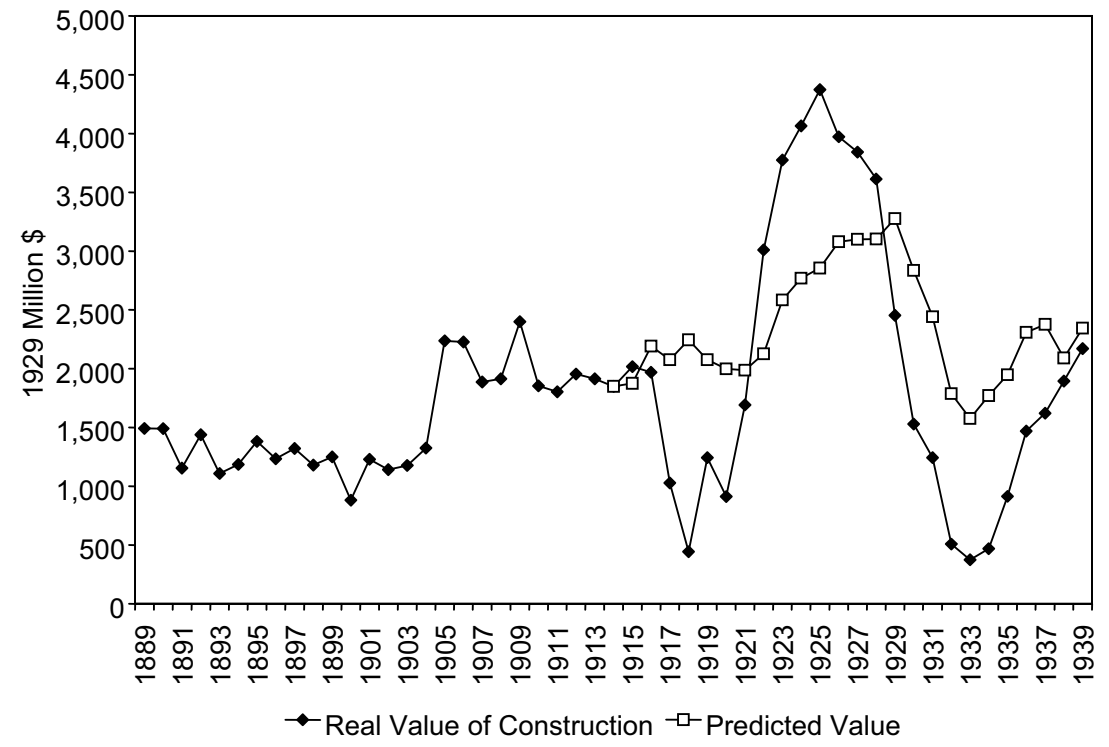

Fig. 4.7 Actual and predicted value of real new residential construction, 1889-1939

Source: Carter et al. (2006, series Dc522) and the text. 
paced growth without the war and increased later as real incomes grew faster, until halted by the Great Depression. While predicted values are below their actual levels in the 1920s, the predicted wartime levels are higher. If we consider the deficit in housing starts during World War I, defined as 1917 to 1920 , there were 1,049,000 starts that never materialized. In contrast there were $1,306,000$ starts in excess of the predicted during the early twenties. The difference, 256,000, might be considered as a measure of the "bubble." While this may seem small, it is two-thirds of the annual average starts for 1900 to 1917. If we examine the value of new construction, there was a shortfall of \$4.9 billion during the years 1917 to 1920 and "excess" construction of $\$ 7.3$ billion during the boom years of the 1920s. Given that the average real value of construction was $\$ 1.8$ billion for 1900 to 1917, a difference of $\$ 2.9$ billion suggests that there was more to the boom than a simple postwar recovery. ${ }^{11}$

\subsection{Was the Federal Reserve Responsible for the Boom?}

Could the Federal Reserve have been responsible for this residual surge in construction? There are two channels through which the Fed could have driven activity higher: (a) a promise by the central bank to prevent a financial crisis, and (b) keeping interest rates abnormally low.

The promise that the central bank will prevent a financial crisis is often called the "Greenspan put." This phrase was coined after the 1998 collapse of Long-Term Capital Management when it was believed that the then chairman of the Federal Reserve Board, Alan Greenspan, would lower interest rates whenever necessary to preserve stability capital markets forgoing price stability. Because this appeared to guarantee an orderly exit of sellers, he was criticized because the moral hazard of such a policy would encourage excessive risk taking, thereby contributing to a boom. In addition to observers on the street, some academics (see Miller, Weller, and Zhang 2002) argue that this policy was at least partially responsible for the subsequent dotcom boom.

A version of this "Greenspan put" may have emerged in the 1920s because the establishment of the Federal Reserve System substantially reduced the threat of crises and panics by changing the stochastic behavior of interest

11. Some observers argued that the spread of the automobile that furthered suburban expansion may have been a new fundamental. To approximate the effects of the automobile and suburbanization in the 1920s, I added a variable, the miles of streets and roads under control of the states, to the regressions (Carter et. al. 2006, series Df184). However, this series only begins in 1904. Given the paucity of observations before 1914, it was not possible to obtain meaningful estimates for out-of-sample forecasts, so the estimated coefficients for a full sample of 1904 to 1939 were used. The coefficient on the variable for roads for the regressions with housing starts and the value of construction was insignificant. There may also be some reason to doubt that suburbanization was responsible for the housing boom. In the absence of the automobile, there could just as easily have been a greater housing boom in the central cities substituting for suburban growth and overcoming the wartime housing deficit. 
rates. As is well known, the Fed was founded in response to the Panic of 1907 and charged in the Federal Reserve Act of 1913 to "furnish an elastic currency." The Fed considered it a central obligation to eliminate the seasonal strain in financial markets, as the first Annual Report emphasized "its duty is not to await emergencies but by anticipation, to do what it can to prevent them." ${ }^{2}$ Miron (1986) documented that the Federal Reserve promptly carried out policies that reduced the seasonality of interest rates. Because panics occurred in periods when seasonal increases in loan demand and decreases in deposit demand strained the financial system, accommodating credit to seasonal shocks reduced the potential of a crisis. Comparing 1890 to 1908 and 1919 to 1928, Miron found the standard deviation of the seasonal for call loans fell from 130 to 46 basis points, with the amplitude dropping from 600 to 230 basis points. ${ }^{13}$ This reduction of seasonality in interest rates lowered the stress on the financial system, leading Miron to conclude that it had eliminated banking panics during the period 1915 to 1929. Most striking was the absence of a panic during the severe recession of 1920 to 1921. Both the timing in the decline of seasonality and the role of the Fed have been challenged, but Miron's basic results have been upheld. ${ }^{14}$ By reducing the volatility of the financial markets, the Fed may have induced additional risk taking, contributing to the real estate boom of the mid-twenties. ${ }^{15}$

In addition to a "Greenspan put," the Fed has been attacked for lax monetary policy in the years preceding the 2008 crisis. John Taylor (2009) has been one of its leading critics. Instead of adhering to policies that match a Taylor rule, as it had in the prior twenty years, he has argued that beginning in 2001 the Fed kept the federal funds rate far below what a Taylor rule would require. The result was that there "was no greater or more persistent deviation of actual Fed policy since the turbulent days of the 1970s," fueling the housing boom of the early twenty-first century. In response, Greenspan argued that although mortgage rates had been tightly correlated with the federal funds from 1971 to 2002, this relationship "diminished to insignifi-

12. Federal Reserve Board, First Annual Report of the Federal Reserve Board (1914, 17).

13. During World War I, the Fed ceded control of the level of interest rates to the Treasury, which wanted to ensure that it could float bonds at low nominal rates. Nevertheless, the Fed first began to dampen seasonals in 1915 by rediscounting bills backed by agricultural commodities at preferential rates, continuing this program until 1918. Gaining control over its discount rate in 1919, the Fed acted more directly. A measure of the Fed's intervention was its credit outstanding. Over the period 1922 to 1928, Miron (1986) calculated that there was an increase in the level of reserve credit outstanding over the seasonal cycle of 32 percent or approximately $\$ 400$ million per year at a time when New York City banks' loans totaled \$6 billion.

14. See Clark (1986), Mankiw, Miron, Weil (1987), Barsky et al. (1988), Fishe and Wohar (1990), Kool (1995), and Caporale and McKiernan (1998).

15. The Fed may also have induced more risk taking by providing banks near the brink of failure with loans from the discount window, contravening the rule that a central bank should lend only to illiquid not insolvent banks. In 1925, the Federal Reserve estimated that 80 percent of the 259 national banks that had failed since 1920 were "habitual borrowers." These banks were provided with long-term credit. A survey in August 1925 found that 593 member banks had been borrowing for a year or more and 293 had been borrowing since 1920 (Schwartz 1992). 
cance" during the boom. Greenspan asserted that global forces were behind this change over which the Fed had little control (Greenspan 2009).

Taylor might have levied the same criticism against the Fed in the 1920s. To measure whether monetary policy was easy or tight, I apply similar Taylor rules to the Federal Reserve in the 1920s. ${ }^{16}$ The Taylor rule is linear in the interest rate and the logarithms of the price level and real output. Using the inflation rate and the deviation of real output from a stochastic trend renders the two variables stationary. The result was a linear equation:

$$
r=\left(r^{*}+\pi\right)+h\left(\pi-\pi^{*}\right)+g y,
$$

where $r$ is the short-term policy interest rate, $r^{*}$ is the equilibrium rate of interest, $\pi$ is the inflation rate and $\pi^{*}$ is the target inflation rate, and $y$ is the percentage deviation of real output from trend. The policy response coefficients to inflation and the output gap are $(1+h)$ and $g$, with the intercept term being $r^{*}-h \pi^{*}$. If $h$ is greater than zero, then the policy rate will rise, not decline, in response to an increase in inflation.

Taylor's original formulation (Taylor 1993) had the federal funds rate adjusted in a fixed response to changes in inflation and the gap in real GDP, which fairly accurately described the then recent policy actions of the Federal Reserve. Even though there was no central bank or instrument like the federal funds rate, Taylor (1999) extended his model to earlier periods. For a period like late nineteenth-century America, which operated under a gold standard without a central bank, there still should have been a relationship between short-term interest rates and inflation. If a shock induced inflation in the United States, the price-specie-flow mechanism would have produced a balance-of-payments deficit with consequent losses of gold, a decline in the money stock, and a rise in interest rates. Similarly, rising real output would have increased the demand for funds and raised interest rates.

In a simple OLS estimate of his equation for the gold standard era, Taylor (1999) found low positive coefficients for inflation and the output gap. ${ }^{17}$ If once the Fed was established, it played by the "rules of the game" and "leaned against the wind," the operation of the adjustment mechanism should have been reinforced and the response coefficients in the Taylor equation should be larger. Taylor did not follow his empirical investigation of the pre-Fed era with one for the 1920s. Instead, he lumped the twenties

16. More generally, Taylor (1999) viewed his work as focusing on the short-term interest rate side of monetary policy, rather than the money stock side. Instead of the quantity equation that had informed Friedman and Schwartz's (1963) analysis of American monetary history, Taylor formulated his monetary policy rule that was derived from the quantity equation.

17. Taylor (1999) estimated equation (1) using ordinary least squares with the commercial paper rate for the years 1879 to 1914 , with inflation measured as the average inflation rate over four quarters. He did not correct for serial correlation, allowing for the possibility that monetary policy mistakes were serially correlated. He pointed out that serial correlation was high under the gold standard, and hence the equations fit poorly and his $t$-statistics are not useful for hypothesis testing. 
and the thirties together and dismissed the Fed's efforts to find an effective rule in the interwar period because of its disastrous performance during the Great Depression. In contrast, Orphanides (2003) offers a more positive Taylor rule assessment of the Fed's actions in the 1920s, but his is a narrative appraisal.

To characterize Fed policy in the 1920s and examine counterfactual policies, I have estimated a Taylor equation for the late nineteenth and early twentieth centuries. Table 4.1 reports the estimates for a Taylor equation on quarterly data for the last years of the classical gold standard 1890 to 1914 and for the interwar gold standard, 1922 to 1929 . The war years and the postwar boom and bust of 1915 to 1921 are omitted because the Fed was not free to operate as an independent central bank but instead served the interests of the Treasury. For 1890 to 1914, the interest rate is the time rate for brokers' loans, rather than the commercial paper rate used by Taylor. The market for brokers' loans was larger than for commercial paper and more closely approximates the market for federal funds as banks often parked excess funds in this market. Using the commercial paper rate or the call rate on brokers' loans did not substantially alter the results. The gross national product (GNP) data were obtained from Balke and Gordon (1986), and the output gap as the percentage deviation of real output from the trend is extracted by a Hodrick-Prescott filter. ${ }^{18}$ The inflation rate is derived from Balke and Gordon's GNP deflator.

The first two rows of table 4.1 report the results for the Taylor equation under the classical gold standard, where the instrumental variables are the second lags on inflation, the output gap, and the time rate. These regressions produce fairly consistent results, recalling that with the lagged dependent variable the estimated coefficients are $(1-\rho) \beta$. Hence the constant is an interest rate of approximately 4 percent. Once adjusted for this factor, the coefficients on inflation and the output gap are in the vicinity of 0.10 to 0.20 , and thus smaller than the coefficients for the last twenty years of the twentieth century when the coefficient on inflation was well over one and on the output gap, somewhat under one, implying that the Fed was pursuing a stable policy. The results are similar to Taylor's (1999) and reflect the behavioral relationships in the absence of a central bank.

Taylor equations are first estimated for 1922 to 1929 using the time rate for brokers' loans. In contrast to Taylor's glum assessment, these results suggest that the Fed acted appropriately, as Friedman and Schwartz (1963) have argued. The response coefficients for inflation and the output gap are positive and significant. Furthermore, they appear to be of an appropriate magnitude once they are adjusted for the presence of the lagged depen-

18. The Hodrick-Prescott filter is used to estimate the trend from 1890.1 to 1930.2. Covering a longer period causes a sharp decline in the trend in 1929 because of the persistence of the Great Depression, creating a huge and unrealistic output gap for 1929. 


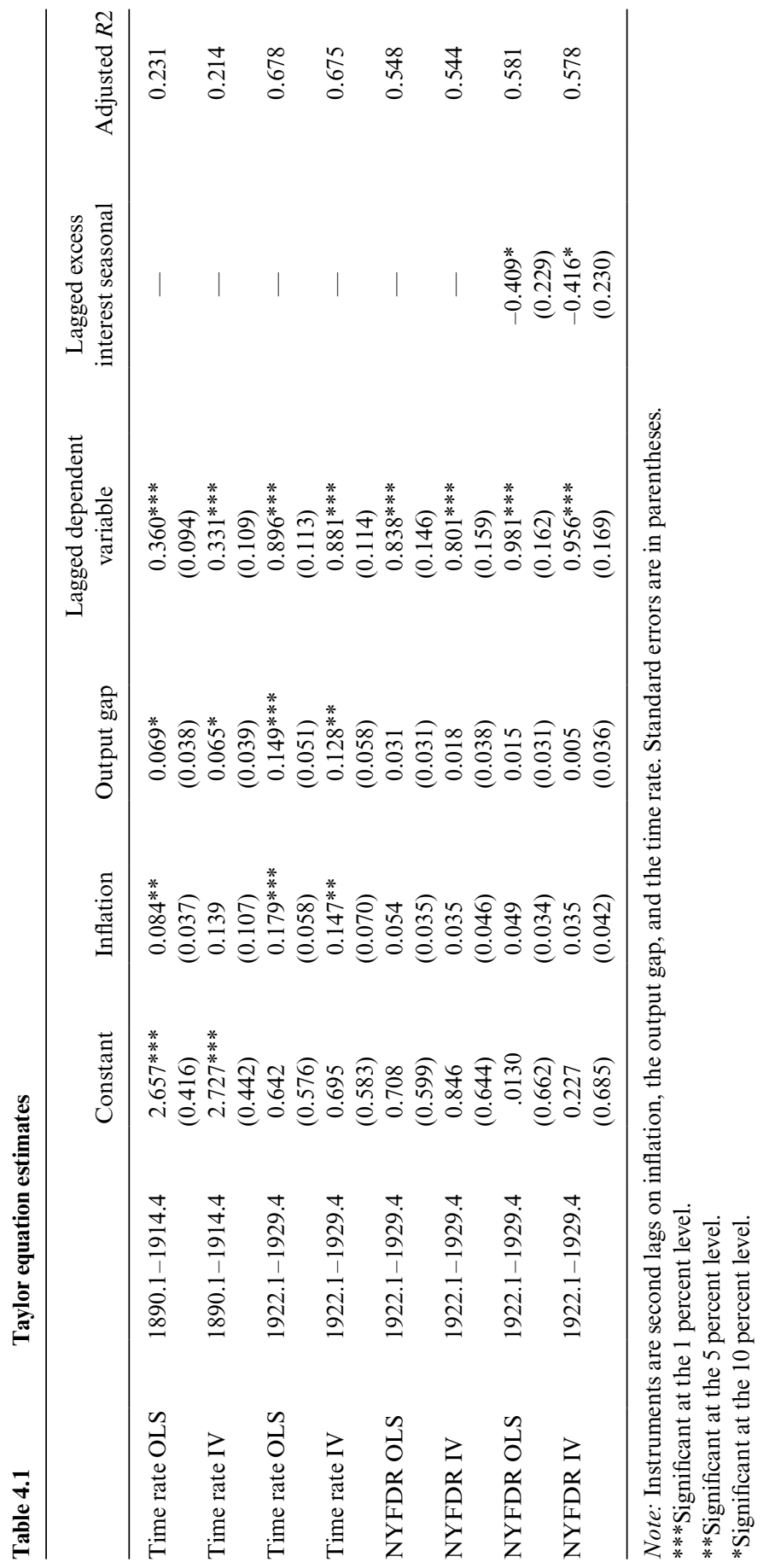


dent variable. The coefficient on inflation has a value greater than one. Of course, the Fed did not operate directly in the brokers' loan market or the commercial paper market, instead its instrument was the discount rate, buttressed by open market purchases and sales. The next two equations apply the same model with the Federal Reserve Bank of New York's discount rate as the dependent variable. Unfortunately, the discount rate was changed infrequently, leading policy to look particularly feeble unless one views its impact through the brokers' loan market where it was apparently robust.

While Taylor's equations capture the focus of contemporary policy, they do not include a measure of the seasonal problems that Miron showed were a vital component of Fed policy. To correct this omission, I include a variable for excess seasonality. Using the time rate, I constructed a centered moving average that deseasonalized the data. Taking the absolute value of the difference between the actual values and the deseasonalized values, I obtained a measure of the degree of seasonality (Wilson and Keating 2002). Although the Fed certainly would have responded more quickly if its efforts to reduce seasonality appeared weak, I include the lagged value of the difference between the time rate and the centered moving average as a measure of the response of the Fed to excess seasonality. In the last two regressions this variable has a negative and significant coefficient, suggesting that it is capturing an important feature of Fed policy even on a quarterly basis. If there was an excessive seasonal in the interest rate, the Fed intervened to reduce it.

By these simple measures, Fed policy in the 1920s appears to have been largely run in accordance with the "rules of the game" while lowering the risk of a panic. This "new regime," appearing in the 1920s, should have increased investor confidence by reducing inflation risk and panic risk. These estimates show that Fed policy moved in the right direction but the question remains as to whether policy was too loose or too tight. To address the counterfactual question of whether the Fed should have conducted policy differently in the 1920s, I apply some simple Taylor rules that have been invoked to judge recent Fed policy.

The first simple Taylor rule is Taylor's original rule with the policy response coefficients set equal to 0.50 . The second rule sets the coefficient on the output response at 1.0 (Taylor 1999). When applied to the second half of the twentieth century, they show that the Fed funds rate was particularly low in the late 1960s, the 1970s, and possibly the late 1990s. In figure 4.8, these two rules are applied to the 1920s, omitting World War I when the Fed purposely kept rates low. It is important to note that the Taylor rule is being applied here when there is no target rate of inflation $\pi^{*}$, as in equation (1). The gold standard promised long-term price stability at the expense of short-term price volatility. In this case, the implicit inflation rate target is zero. The Fed funds rate real rate is assumed in the Taylor rule to be 2.0 percent. However, this value cannot be used for the earlier periods because the real rate for the time rate on brokers' loans was higher because they had more risk. The 


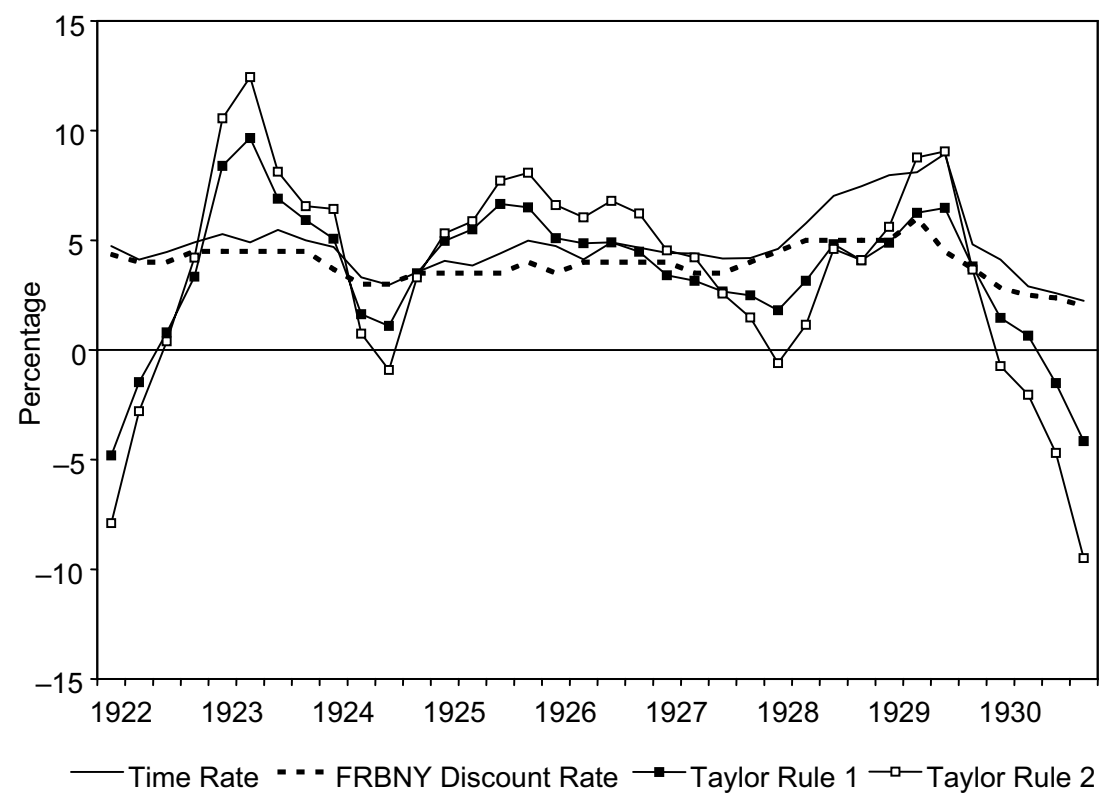

Fig. 4.8 Taylor rules and the rate of interest, 1922-1930

nominal rate averaged 5 percent for 1922 to 1929 , but was closer to 4 percent before the stock market bubble of 1928 to 1929 distorted it (Rappoport and White 1994). Taking into consideration a zero inflation rate target, the real rate of interest was 4 to 5 percent. A value of 4 percent is used to construct figure 4.8 , though a 5 percent value yielded similar results.

The Taylor rules have a greater amplitude than the time rate or discount rate, suggesting that that Fed policy, while appropriate, was not sufficiently vigorous. Of course, the rule is not a precise formulation of policy as it would sometimes dictate negative rates of interest. ${ }^{19}$ Could the Fed have pursued even stronger policies in the 1920s? What is the importance of the gap between the actual interest rates and the counterfactual Taylor rates? Taylor (1999) found that policy was first too loose in the early 1960s when the gap between the federal funds rate and Taylor rule 1 was at 2 to 3 percent for three and a half years. Then, in the late 1960s to the late 1970s, it rose to 4 to 6 percent creating the "Great Inflation." Taylor's counterfactual for 2001 to 2006 pointed to a policy gap as great as 3 percent. Taylor rules in figure 4.8 suggest that policy should have been eased more quickly during the severe contraction of 1920 to 1921 . It was too easy in the following boom and too tight in the short recession that followed. For the housing market,

19. Taylor $(1999,338 n 13)$ recognized this problem for analyzing alternative policy in the 1960 s. 


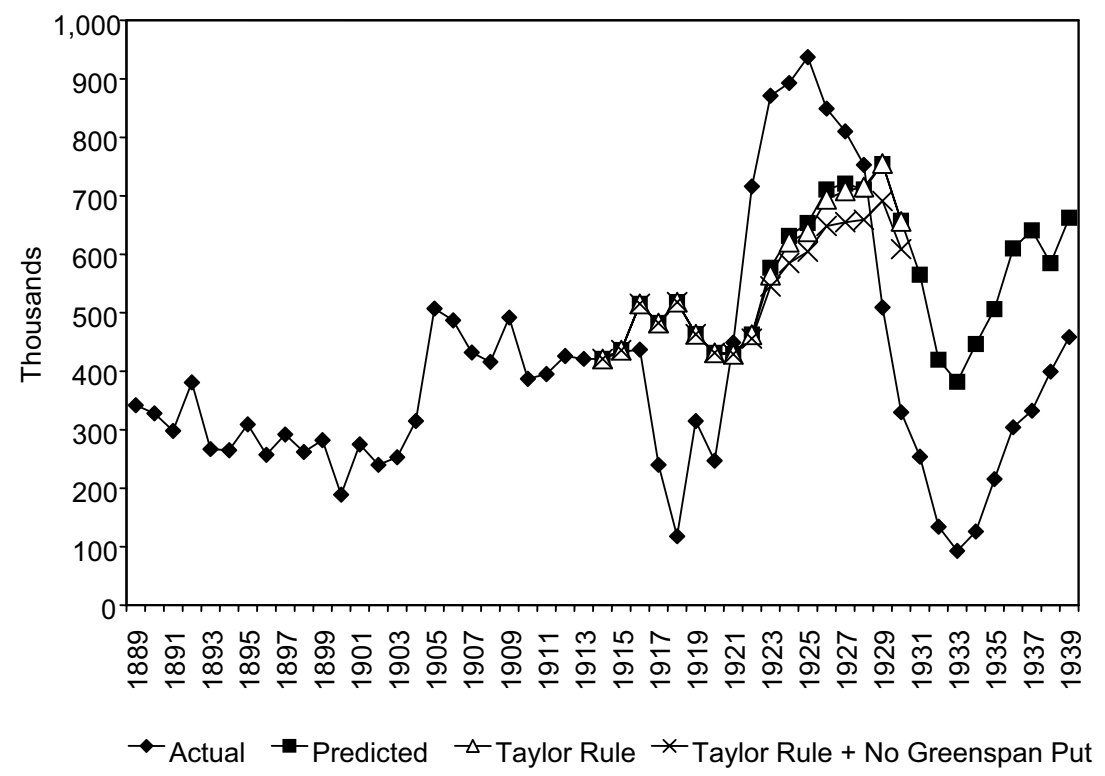

Fig. 4.9 The effects of alternative monetary policies on housing starts

it appears that policy eased considerably beginning in 1925 and remained loose through 1926 with the gap between the market rate and the counterfactual, peaking at 2 percent for Taylor rule 1 and staying above 2 percent for Taylor rule 2 from 1925.2 through 1926.3. These years were crucial for the housing boom and suggest, at least by the measure of the early 1960s, that the magnitude of the error was substantial and may have contributed to igniting a housing boom.

What impact could different monetary policies have had on the housing boom of the 1920s? Figure 4.9 shows the actual and predicted movements in housing starts depicted in figure 4.6. The only difference is that the predicted housing starts use the time rate on brokers' loans rather than a mortgage rate. The results differ very little but permit an exercise in counterfactual monetary policy. ${ }^{20}$ The first question is what would have happened to housing starts if monetary policy had followed Taylor rule 1 . The effect of the policy is measured as the difference between predicted housing starts and the Taylor rule. As is evident, the higher interest rates during the boom that the Taylor rule would have required would have had scant impact on housing starts.

The effects of abandoning the Greenspan put are greater, as seen in figure

20. As already noted, mortgages rates during the 1920s were quite flat and apparently unresponsive to the fluctuations in short rates. For the twenty-first century bubble, this phenomenon was also noted by Taylor (2007) who attributed it to perceived changes in the responsiveness to inflation in short rates. In the 1920 s, long-run inflation would have been checked by the gold standard and thus have steadied longer rates. 
4.9 with a line that combines the effect of the Taylor rule plus the Greenspan put. This effect is measured by forecasting out of sample, using a regression that adds the excess seasonality variable. In the forecast, the excess seasonality of the pre-Fed era, averaging 0.74 is substituted for the actual values that averaged 0.25 in the 1920s. The results of this exercise show that if the Fed had allowed seasonal rates to fluctuate as they had before 1914 there would have been a reduction in starts. Over the period 1922 to 1926, this "put" combined with tighter Taylor rule policy would have lowered housing starts by 196,000 . The excess housing starts - the difference between the actual and predicted starts - was 1,306,000 for these years, suggesting that a different policy would have had little effect. If on the other hand, one believes that the higher postwar housing were mostly a catch-up from the wartime deficit, then there were only excess housing starts of 256,000. A reduction of 196,000 starts would have virtually eliminated this excess, suggesting that a different policy could have limited the extremes of the boom.

Of course, Federal Reserve policy in the 1920s was not focused on the housing markets. The alternative policy suggested previously would have been a radical departure from the mandate given in the Federal Reserve Act, and no one suggested that it should abandon its established policy. Even if the Fed had wanted to include the housing market in its policy deliberations, there were no national indices, as there were for industrial production. The Federal Reserve was more focused on short-term rates, which it could directly influence and whose importance was validated by the real bills doctrine that emphasized the centrality of short-term finance (Friedman and Schwartz 1963; Meltzer 2003; Wicker 1966; Wheelock 1991). Longer-term interest rates that played a role in the housing market drew far less attention than brokers' loan and related short-term rates that influenced the stock market boom. Centered in New York, the capital markets captured the concern of the Fed, but the housing market still had strong regional elements, yielding a more complex and less easily interpreted picture. Thus, the more realistic counterfactual of following a Taylor rule but not eliminating the put leaves a substantial housing boom.

\subsection{A Reduction in Lending Standards?}

A decline in lending standards, leading to an expansion of the mortgage market, is often cited as an important contributing factor in the boom of the early twenty-first century and the collapse of the financial sector. The expansion of mortgage credit in the 1920s was also facilitated by a loosening of lending standards with aggressive new intermediaries increasing their market share. Although the evidence for the twenties is fragmentary, there appears a more modest drop in lending standards for mortgages held by financial institutions.

The real estate boom of the 1920s saw an upswing in mortgage financing, fostered by the expansion of new entrants into the business. Mortgage fund- 


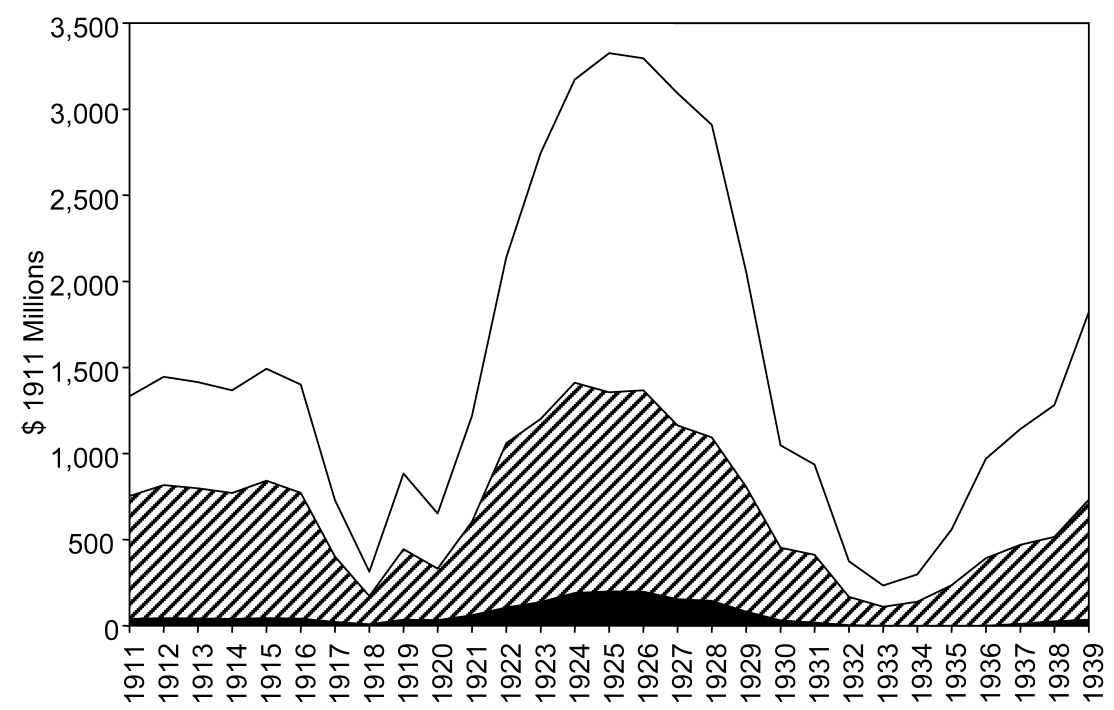

- Sales Contracts $\square$ Equity Finance $\square$ Mortgage Finance

Fig. 4.10 Sources of funding for residential construction, 1911-1939

Sources: Grebler, Blank, and Winnick (1956, table M-1).The values are deflated by the Consumer Price Index. Carter et al. (2006, series Cc1).

ing, which had accounted for less than 45 percent of residential construction finance before World War I, rose to nearly 60 percent at the height of the boom. Depicted in figure 4.10, this change shows the rise in the real funding of residential construction by source. Mortgages, which had constituted less than half of funding in the prewar years, supplied over $\$ 2$ billion of the $\$ 3.3$ billion in financing for 1926.

One force behind the increase in mortgage finance was the shift in the sources of finance. Mortgage funding by source is shown in figure 4.11. Noninstitutional lending - friends, family and private local individuals — had been slowly declining since the turn of the century when it had accounted for over half the market. In the boom it fell further from 42.2 to 37.1 percent between 1920 and 1926. Mutual savings banks, which had been the largest source of institutional lending before the First World War, saw their share shrink from 19.5 to 17.6 percent over the same period. The more aggressive lenders gained ground in this short period, with commercial banks expanding from 8.8 to 10.8 percent, insurance companies from 6.2 to 8.1 percent, and savings and loans associations from 20.4 to 23.2 percent. These three innovators expanded their total mortgages by 76,79 , and 62 percent in these six years. ${ }^{21}$

21. Information on the sources of mortgage funding is found in Carter et al. (2006, series Dc903-928). 


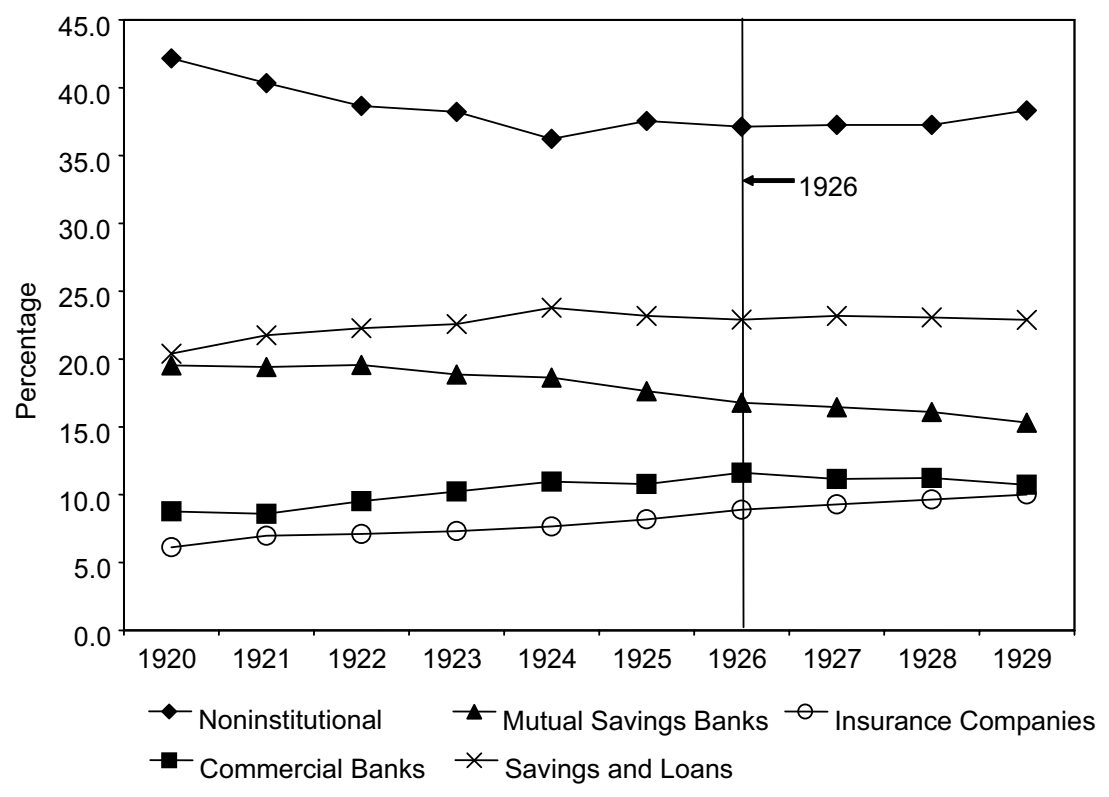

Fig. 4.11 Shares of mortgages lending by source

Source: Carter et al. (2006, series Dc907-911).

Before reviewing the available data on how the terms of mortgages changed, it is important to note that the long-term fixed interest amortized mortgage that became a standard in the early post-World War II era was uncommon before the Great Depression. Most mortgages were short-term, many had only partial or no amortization with very low loan-to-value ratios, and balloon mortgages were not uncommon. Thus, the heterogeneous contemporary mortgage market resembles more its pre-Depression ancestor than the market in the first three to four decades after World War II when there was a greater standardization.

The only detailed source of data for mortgage contracts in the 1920s is Morton (1956), who drew upon samples of loan portfolios for several hundred financial institutions. Of course, these were institutions that had survived the ravages of the Great Depression and presumably had followed more conservative practices than those that disappeared. Yet, even taking into account this survivor bias, the changes in lending for the three fastestgrowing mortgage lenders appear to be far from reckless.

Commercial banks eased terms, letting their nonamortized loans increase from 41 to 51 percent in the loans sampled for 1920 to 1924 and 1925 to 1929 , while the share of fully amortized loans dropped from 15 to 10 percent. The average contract length was approximately three years. Thus, the most common loans at commercial banks were nonamortized "balloon" mortgages 
of short duration. From the lenders' point of view these were hardly risky loans as the loan-to-value ratios averaged just above 50 percent. ${ }^{22}$

Although often termed savings and loan associations, the pre-Depression building and loan associations had both professional full-time firms and part-time associations that pooled members' weekly or monthly dues to lend to members to buy homes. Many of the latter were managed by real estate professionals and builders who had conflicts of interest. In contrast to commercial banks, amortized loans dominated the portfolios of building and loan associations, constituting 95 percent of the mortgages sampled. The contract lengths were almost all under fifteen years, with a mean length of eleven years. The B\&Ls were one of the market innovators, developing low down payment mortgages. One product was the "Philadelphia Plan" where a B\&L would issue a second amortized mortgage for 30 percent of the property value after the borrower had a first, interest only loan from a bank or other intermediary for 50 percent of the value. Eventually, the B\&Ls began to issue both mortgages, even though some in the industry raised concerns about the increased risks to borrower and lender (Snowden 2010). These "affordable" products enabled the B\&Ls to grab a greater market share during the boom.

Insurance companies offered a more varied mix of loans than either B\&Ls or commercial banks in the 1920s, giving 20 percent nonamortized loans in the first half of the decade and 24 percent in the second half. Less than 20 percent of these mortgages were fully amortized. Contract length for loans from insurance companies averaged six years but had greater variance than other institutions with 20 percent lasting zero to four years, 51 percent five to nine years, and 26 percent ten to fourteen years.

As most observers noted, interest rates for mortgages were relatively "sticky" - moving very little over long periods of time - in comparison to other long term interest rates, such as bond yields. Grebler, Blank, and Winnick (1956) provide some data on interest rates by cities shown in figure 4.12. The first series for Manhattan was taken from the Real Estate Analyst. The authors composed the second series from the Real Estate Record and Guide, where the interest rates were weighted by the dollar value of all reported loans for March, July, and November. Similar data were available for the Bronx, which they considered to be almost entirely residential real estate and hence a better reflection of that market. Lastly, the authors compiled the St. Louis series from the Real Estate Analyst and the St. Louis Daily Record, which they believed was primarily for one-to-four family home mortgages. ${ }^{23}$

22. It is very conservative compared to the norms of the past three decades. From 1980 to 2007, the loan-to-value ratios for conventional single-family mortgages varied between 73 and 79 percent (Joint Center for Housing Studies of Harvard University 2008, table A-3).

23. Grebler, Blank, and Winnick (1956) also report a Chicago series from the graphs in Homer Hoyt's One Hundred Years of Land Values in Chicago (1933). They regarded Hoyt's rates as crude approximations for the value of property in the central business district. The Chicago series is not reported here as its value seems dubious given that reported rates remained fixed for decades then experienced huge jumps. 


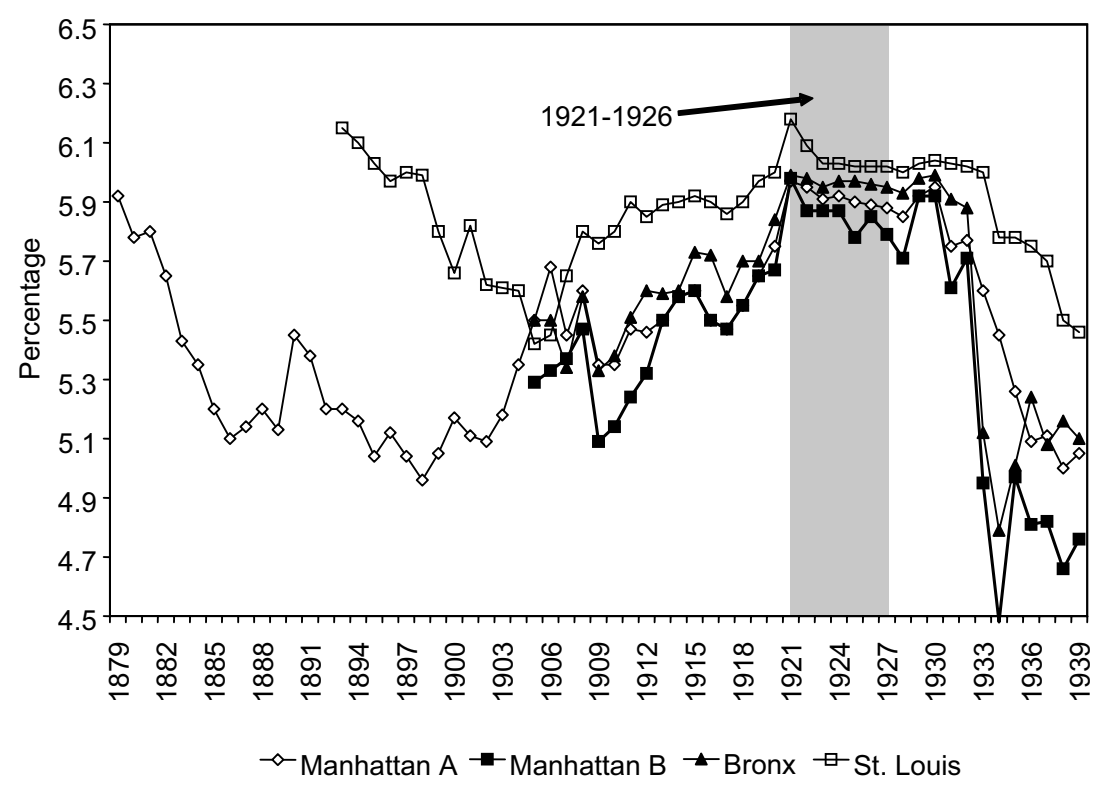

Fig. 4.12 Mortgage rates by city, 1879-1939

Source: Grebler, Blank, and Winnick (1956, table O-1).

Three facts emerge from figure 4.12. First, St. Louis rates are higher, perhaps reflecting high regional premiums. Second, and most importantly, rates were relatively more volatile in the years before the founding of the Fed, a fact which is consistent with the behavior of short-term rates. The 1920s appear to be remarkably stable with very little movement in Manhattan, the Bronx, or St. Louis. Third, the mild decline in rates shown in the national sample contract data reported by Morton (1956) is also present for the city-level data. Overall, the impetus to a real estate boom in the 1920s from a reduction in the level of mortgage rates seems minor, given the very small declines and the lower rates that persisted before the founding of the Federal Reserve. However, if stability was a spur to the boom, as the econometric evidence suggests in the previous section, then the 1920s market had a new stimulus.

While it is difficult to draw a definitive conclusion from this admittedly patchy data, the changes in lending standards and mortgage rates in the 1920s seem quite modest, except perhaps for the building and loan associations. It is unlikely that the expansion of mortgage lending exposed financial intermediaries to significant risk because of the very conservative loanto-value ratios, typically of 40 or 50 percent. Even with a loan-to-value ratio of 20 percent, the B\&Ls seem relatively cautious, though their contemporaries thought they were taking excessive risks. In general, even though housing prices fell significantly, there was little potential for a financial crisis after 1926 because mortgages originated and held by financial institutions only 
carried a modest risk, barring an unforeseen cataclysm such as the Great Depression. The real estate collapse that followed 1926 did not fall into that category, as the market showed some signs of recovery in 1929.

\subsection{Reckless Securitization?}

The 1920s also witnessed a wave of securitization of residential and commercial mortgages. ${ }^{24}$ Real estate bonds were issued against single large commercial mortgages or pools of commercial or real estate mortgages. Singleproperty bonds financed construction of commercial buildings, notably offices, hotels, apartments, and theaters, in major cities. Figure 4.13 shows the annual increases in outstanding mortgage debt and real estate bonds. Although mortgage debt approximately doubled between 1922 and the peak, the growth of real estate bonds is impressive, with residential bonds representing a key component. ${ }^{25}$ The experience of this bond market parallels the contemporary development of subprime securities. Both constituted modest but important shares of the market and both had much more dismal investment outcomes than mortgages directly held by financial intermediaries. ${ }^{26}$

Critical to the development of the real estate bond market was New York State's legalization of private mortgage insurance in 1904, after which securitization blossomed in the state. Title and mortgage guarantee companies were permitted to offer insurance not just against a defect in a land title but also against the nonpayment of mortgages. These companies began to originate and sell mortgages, servicing them after sale. In a development similar to the contemporary role of Fannie Mae and Freddie Mac, these firms provided explicit default insurance policies, promising purchasers that they would have a default-free income stream from investing in participation certificates in mortgage pools. In the absence of a secondary market, the bond houses offered to repurchase the securities, in effect giving a put to their customers. These policies were apparently unhedged and concentrated risk in the originating companies, subsequently contributing to widespread failures.

To protect the buyers, title and mortgage insurance companies were required by law to maintain a reserve fund, expressed as a percentage of their capital and surplus rather than the volume of their outstanding insurance commitments. They were thus constrained more by their reputation than regulation to set aside sufficient reserves. Transparency was limited

24. This description draws heavily on Snowden's (1995) history of American mortgage securitization.

25. The aggregate figures for mortgage debt and real estate bonds omit many small issues that began to flood the market in 1925, which in itself was an indicator of the boom. See Fisher (1951).

26. For instance, Alt-A and subprime mortgages each constituted 13 percent of the total new mortgage-backed securities in 2006. See Coval, Jurek, and Stafford (2009), Gorton (2008), and Mayer, Pence, and Sherlund (2009). 


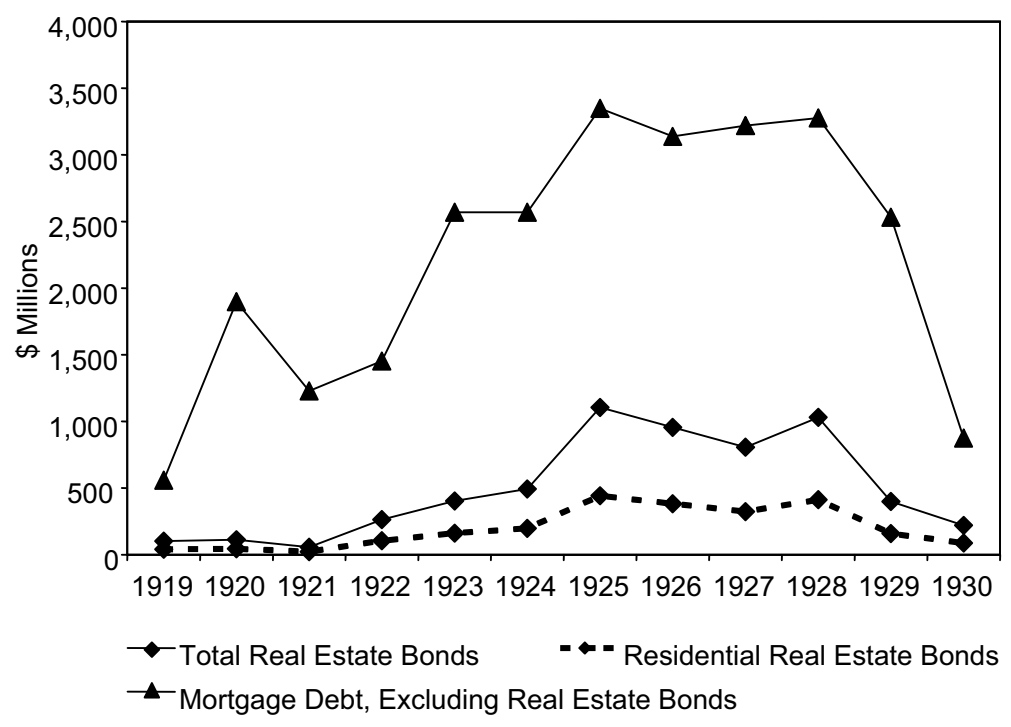

Fig. 4.13 Increases in the outstanding mortgage debt and real estate bonds, 1919-1930

Sources: Grebler, Blank, and Winnick (1956) and Carter et al. (2006, series Dc904-906).

as the companies served as their own depositories and could substitute new loans for the original mortgages. There were claims that companies had loans on foreclosed land and poorly appraised properties. According to Snowden (1995), New York regulators were overwhelmed and did not examine whether the loan-to-value ratio was the legal 50 percent; they simply accepted the claimed value. Yet, investors purchased these bonds reassured by insurance, approval of the regulators, and favorable assessments by rating agencies. In addition, Snowden (1995) concluded that the singleproperty real estate bonds were-evaluated by rating agencies, including Moody's - not subject to stringent standards. ${ }^{27}$ Apparently, the public did not even take into account observable features of the bonds and mispriced risk. In an econometric examination of a sample of 125 real estate bond prospectuses, Goetzmann and Newman (2010) found that investors did not demand default or term premia but relied on the reputation of the bond houses that managed the issues, leading the authors to view investors in real estate bonds as exceedingly optimistic.

The development of these opaque securitized mortgages appears to be a precursor of growth of the securitized subprime mortgages in the early twenty-first century. Like the subprime mortgages, where quality declined rapidly with vintage, the quality of the real estate bonds rapidly deteriorated 
Table 4.2

Performance of real estate bonds, 1919-1931

\begin{tabular}{cccc}
\hline Year & Number of issues & Value millions (\$) & $\begin{array}{c}\text { Percent not } \\
\text { meeting contract }\end{array}$ \\
\hline 1919 & 13 & 31.2 & 1.9 \\
1920 & 19 & 48.2 & 20.8 \\
1921 & 13 & 24.2 & 29.8 \\
1922 & 62 & 137.8 & 27.6 \\
1923 & 67 & 165.4 & 41.8 \\
1924 & 96 & 197.7 & 50.9 \\
1925 & 178 & 483.6 & 58.3 \\
1926 & 177 & 431.3 & 68.0 \\
1927 & 163 & 379.2 & 72.1 \\
1928 & 209 & 519.0 & 77.0 \\
1929 & 62 & 176.3 & 57.4 \\
1930 & 23 & 77.2 & 27.1 \\
1931 & 8 & 12.9 & \\
\hline
\end{tabular}

Source: Johnson (1936, table II).

Note: The source omits all bonds issued under \$1 million.

as the boom progressed (Wiggers and Ashcraft 2012). Johnson (1936) examined the fate of commercial real estate mortgages over $\$ 1$ million, by year of issue. His data for 1919 to 1931 is presented in table 4.2, which shows the number and value of issues per year and whether the bonds met their contractual obligations. It should be remembered that while the residential market peaked in 1926, the commercial market continued to flourish through the rest of the decade. Interpretation of the table is made more difficult by the Great Depression, which independent of the bubble's collapse, caused borrowers to fall into arrears and default. Nevertheless, as the number of issues rose sharply from 1923 to 1926 , the long-term performance of the bonds deteriorated sharply. Wiggers and Ashcraft (2012) provided new data that shows this deterioration was in evidence before the Depression. Drawing upon a sample of 3,800 bonds, they estimated the cumulative default rates of bonds issued between 1920 and 1932. For 335 bonds issued in 1923 and 331 issued in 1924 there were cumulative three- and five-year default rates of 0 and 0.5 percent for 1923 and 2 and 5 percent for 1924. Moving into the boom years of 1925 and 1926, there were 528 and 512 bonds issued with three- and five-year cumulative rates of 4.4 and 11 percent for 1925 and 3 and 18.9 percent for 1926.

More detail is available for the important Chicago market, which shows a similar picture. Using data from Moody's 1936 edition of Banks, Insurance, Real Estate and Investment Trusts, Koester (1939) identified the 285 largest issues that raised $\$ 536.5$ million. Twenty-eight percent were for apartments, 22 percent for apartment hotels, 10 percent for hotels, 21 percent for office buildings, and the remainder miscellaneous. Most of the issues - 190 
(\$264.9 million) - were underwritten by real estate specialists, with investment bankers offering 50 issues ( $\$ 160.0$ million) and banks or their securities affiliates serving forty-five issues ( $\$ 72.5$ million). Defaults first began to appear in 1925. Between 1925 and 1928, seven issues representing \$8.3 million defaulted, rising to twenty-two issues in 1929, whose face value was \$29.3 million. By 1931, 69 percent of all bonds were in default; and finally 95 percent in 1936. Although the Great Depression wrought havoc on this market, a surprising 10 percent of bonds representing 7 percent of aggregate value defaulted during a period of healthy economic growth. For the United States as a whole, it is estimated that 60 percent of all mortgages were in arrears and one-third of all loans defaulted in the 1930s, leading to the ruin of the guarantee companies that had provided the insurance (Snowden 1995).

Like the contemporary subprime issues (Gorton 2008), there was initially no market for single-property mortgages, and an attempt to create an exchange failed; instead, a market was maintained by the originating houses that initially promised to repurchase the securities from investors. The market for single-property mortgages was ephemeral, with the first bond house failing in 1926. Yet, the key difference with the early twenty-first century is that these securitized mortgages were held primarily by investors, not financial institutions; thus, unlike today, the bust in the real estate bonds did not produce bank insolvencies. National banks appear to have held little or no real estate bonds. Most of the securities in their portfolio were issued by the federal government and averaged about 10 percent of assets during the 1920s. The remainder was primarily state and local government bonds, and these accounted for only 2.5 percent assets, risking at the very most 20 percent of capital. For the same period, state banks held 6.5 of their assets in US government bonds and 3.3 in state and local securities, the latter accounting for 52 percent of capital. Thus, banks held very few risky real estate bonds in their portfolios. ${ }^{28}$

\subsection{Riskier Banks?}

While there were changes in the quality of assets, the overall risk to which financial institutions were exposed during the 1920s needs to be assessed. Risk taking by financial institutions in the boom of 2000 to 2006 was cloaked by use of off-balance sheet operations, but these were nonexistent in the 1920s. ${ }^{29}$ Therefore, movements in the capital-to-asset ratios should capture much of financial institutions' exposure to risk. However, there were two features of banking in this era that need to be considered first - the de-

28. These statistics are calculated for the years 1922 to 1928 , when there is relatively little variation. See Carter et al. (2006, series Cj158, Cj169, Cj212, and Cj225).

29. For a detailed description of the contemporary off-balance sheet activities of financial institutions, see Pozsar et al. (2012). 
velopment of universal banking, and the general rule of double rather than simple limited liability for shareholders.

Some observers have blamed the recent banking collapse on the abandonment of the Glass-Steagall Act and the re-emergence of universal banking in the United States. ${ }^{30}$ Given the passage of the Gramm-Leach-Bliley Act in 1999 that allowed the formation of Financial Holding Companies, combining commercial banking, investment banking, and insurance, the timing seems correct, although the barriers between these industries had been slowly eroding since the late 1980s (Crockett et al. 2003). The Glass-Steagall Act of 1933 was originally inspired by the alleged excesses of the earlier form of universal banking in the 1920s where commercial banks entered investment banking via securities affiliates. This episode was intensively investigated before the passage of the 1999 act, and the evidence revealed that the allegations made in Congress and in the popular press were not true for the industry as a whole. In fact, pre-Great Depression universal banks issued less risky securities that had fewer defaults than stand-alone investment banks (Kroszner and Rajan 1994, 1997; Puri 1994). Universal banks were not more risky than stand-alone commercial banks and relatively fewer failed during the Great Depression (White 1986). Furthermore, most of these securities affiliates were started after the real estate boom ended and as the stock market boom heated up, focusing their activities on corporate and sovereign debt rather than real estate bonds.

Banks in the 1920s differed significantly from early twenty-first century banks because they typically did not have simple limited liability (Grossman 2001). Instead, double liability was the rule, where shareholders were held liable equally and ratably. National banks had double liability, where each shareholder was "liable to the amount of the par value of the shares held by him, in addition to the amount invested in such shares." The potential effect of inducing shareholders to increase their efforts to control risk taking and monitor management was well understood. For state-chartered banks, all but about ten states had adopted double liability by the 1920s. The remainder had single, triple, or individually determined liability. For the national banks, Macey and Miller (1992) found that recovery rates from shareholders averaged 51 percent in the pre-FDIC era and concluded that double liability made shareholders more cautious and willing to intervene. Consequently, troubled banks preferred a voluntary liquidation, rather than waiting for an involuntary insolvency. Bank assets were transferred to new investors without a costly bankruptcy proceeding and assessment, leaving creditors and depositors paid in full. Examining the period 1892 to 1930, Grossman (2001) found that on average there were fewer bank failures, less risk taking,

30. As an example of the popular belief that repeal of Glass-Steagall contributed to the recent crisis, see Sanati (2009). 


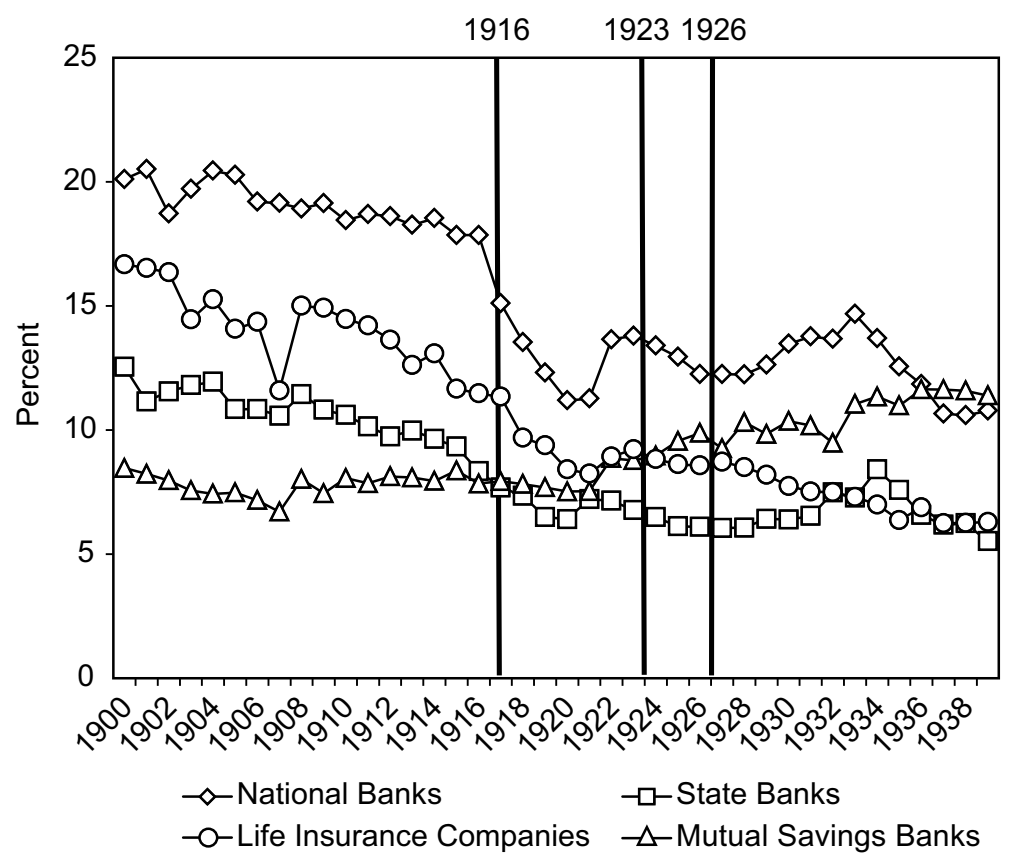

Fig. 4.14 Capital-asset ratios for selected financial intermediaries, 1900-1940

Source: Carter et al. (2006, series Cj217, Cj236, Cj159, Cj175, Cj362, Cj374, Cj741, and Cj750).

and higher capital-to-asset ratios in states where there was double or multiple liability. ${ }^{31}$ Overall, the different liability rules of the 1920 s seem to have improved the quality of corporate governance.

Figure 4.14 presents the capital-to-asset ratios for several institutions for 1900 to 1940 . There were no federal or state capital-asset requirements in this era, thus the ratio should capture bankers' decisions. Commercial banks were the dominant institution with 63 percent of the assets of all financial intermediaries in 1922. This share was almost evenly divided between national banks, which were typically larger and more diversified, and state banks that were often very small. Mutual savings banks had 9 percent and life insurance companies nearly 12 percent of all assets in 1922. Savings and loans had 4 percent of assets but unfortunately there is no data on their capital for this period (Goldsmith 1958).

The figure shows the long decline in the capital-to-asset ratios that began

31. In later research, Grossman (2007) found that in the nineteenth century rapidly growing states on the frontier tended to adopt single liability to encourage the growth of banking while double liability was adopted in states where the banking sector was more developed. 
in the nineteenth century. ${ }^{32}$ Yet, even in 1916, on the eve of America's entry into World War I, the ratio stood at 17.8 percent for national banks, 8.3 percent for state banks, 7.8 percent for mutual savings banks, and 11.5 percent for insurance companies. By contemporary standards this would be considered a very well-capitalized industry. Part of this high level reflected the need to reassure depositors, who were unprotected by deposit insurance; but it also was indicative of the fact that many banks were small, undiversified, single-office operations requiring higher levels of capitalization.

World War I produced an abrupt departure from the gradual downward trend, with the ratio falling to 11 percent for national banks and 6 percent for state banks by 1920. The source of this decline is well known (Friedman and Schwartz 1963). To fund the war, the federal government induced the banks to expand their portfolios by buying bonds and providing loans secured by the purchase of bonds. Following the severe 1919 to 1921 recession, banks raised the ratio by holding asset growth in check and increasing capital. From 1923 to 1926, the capital-asset ratio resumed its decline with asset growth driving down the ratio. Suggestively, this ratio halts at the end of the real estate boom in 1926 only to rise again when banks were faced with the prospect of large losses in the depression. This aggregate data hints that banks became somewhat more risky during the real estate boom, but leaves open the question whether the bust threatened their solvency.

The most detailed data available on the threat to solvency from a decline in the value of real estate loans is for national and state banks. While their capital decisions were not constrained by regulations, their portfolios choices were. The National Banking Act of 1864 had imposed severe limitations on mortgage loans for national banks. Outside the central reserve cities of New York, Chicago, and St. Louis, banks were allowed to grant loans up to five years' maturity on real estate provided that each loan was worth less than 50 percent of the appraised value of the land. Furthermore, total real estate loans could not exceed 25 percent of a bank's capital (White 1983). In 1920, national banks held only 1.7 percent of their assets in real estate loans, but by 1926 this had risen to 5.4 percent. Driving this change was an increase in total mortgage loans from $\$ 371$ million in 1922 to $\$ 725$ million in 1926. In this latter year, national banks had a total loan portfolio of $\$ 13.3$ billion and capital of $\$ 3.1$ billion so that real estate loans equaled 23 percent of capital, just below the legal limit of 25 percent. The low degree of leverage ensured that even a complete loss on these real estate loans could have been easily absorbed by capital. Actual losses were relatively modest. Net loan losses in 1926 were $\$ 109$ million and totaled \$50 million in 1927, lower than the \$118 million average annual losses for 1921-1925. The burden of these losses was,

32. Berger, Herring, and Szëgo (1995) chart the decline in commercial banks' capital-to-asset ratios and blame its long-term decline on the National Banking Act protections for national bank notes and the Federal Reserve's actions as a lender of last resort. 
of course, not equally distributed. National bank failures had risen because of the post-World War I agricultural problems, with annual suspensions climbing from 21 in 1921 to 123 in 1926, but they declined in 1927 and 1928 to 91 and then 51 (Board of Governors 1943). If real estate losses from the bust had been severe, one would have expected an increase rather than a drop. Furthermore, most failures were in agricultural areas, unaffected by the boom in residential real estate (Alston, Grove, and Wheelock 1994).

More difficulties might have been expected for state banks because state regulations on real estate were weaker. The only survey of state regulations that is proximate in time is Welldon (1909), a decade and a half earlier. However, since state regulations changed slowly and there was a tendency to weaken rather than to strengthen them (White 1983), it should be a fairly accurate guide for the 1920s. Welldon found that only twelve states imposed any restrictions on commercial banks, and most rules tended to be weak. California and North Dakota limited real estate loans to first liens. Ohio and Texas restricted real estate loans to 50 percent of all assets, while South Carolina and Wisconsin set a limit of 50 percent of capital and deposits. The only strict states were Michigan, where real estate loans could not exceed 50 percent of capital, and New York, where rural banks could not have real estate loans in excess of 15 percent of assets and city banks in excess of 40 percent.

In general, real estate loans bulked much larger in the portfolios of state banks. They accounted for 14 percent of assets and 23 percent of all loans on the eve of the boom in 1922. State banks' real estate loans rose from $\$ 3.3$ billion in 1922 to $\$ 5.1$ billion during 1926, reaching 16 percent of assets and 27 percent of all loans. In the few states that regulated these loans, some state banks may have reached their legal limits, but most seem to have been well below them. Unlike national banks, real estate loans did exceed capital. In 1926, they were two and a half times capital for all state banks. Clearly, substantial losses on these loans could have produced widespread bank insolvencies.

Nevertheless, state banks do not seem to have taken on much more risk than national banks. The pattern of bank suspensions was no different from the national banks for these more numerous and smaller institutions (There were 21,214 state banks and 8,244 national banks in 1922). Suspensions rose from 409 banks in 1921 to a peak of 801 in 1926, which historians have attributed to the postwar collapse of agricultural prices (Wheelock 1992a). The real estate bust should have added to their woes, but instead suspensions fell to 545 in 1927 and 422 in 1928 (Board of Governors 1943, table 66). Commercial banks were clearly not endangered by the collapse of the real estate bubble in spite of the expansion of mortgage lending. They remained prudent, limiting the share of real estate loans in their portfolios and demanding substantial collateral.

Life insurance companies were among the more aggressive lenders in the 
1920s. Mortgages as a share of assets rose from 36 percent in 1922 to 43 percent in 1926. Large losses here could certainly have driven these companies into insolvency as their capital-to-asset ratios were 8.2 percent in 1922 and 7.8 percent in 1926 (Carter et al. 2006, series Cj741, Cj744, and Cj750). While there is less data on these institutions, there is no record of any major insurance company failures in the 1920s and they appear to have been quite profitable. Data is also limited for savings and loan associations. Mortgage loans constituted 90 percent of their assets in 1922 and 92 percent in 1926. Similarly, there is no record of any uptick in S\&L failures and unlike commercial banks, the number of savings and loan associations continued to grow through 1927 (Carter et al. 2006, series Cj389, Cj390, and Cj391).

Mortgage loans were central to the mission of mutual savings banks and constituted 92 percent of their loans and 43 percent of their assets in 1922. These institutions lost market share and appear to have adhered to their traditional lending standards, even though their real estate lending jumped from $\$ 2.7$ to $\$ 4.3$ billion. At the peak of the boom in 1926, these loans represented 95 percent of loans and 52 percent of assets (Carter et al. 2006, table Cj362-374). In spite of this apparently high level of exposure, only two mutual savings banks failed in the 1920s, one in 1922 and one in 1928 (Board of Governors 1943, table 72).

Taking this information together, it is hard not to reach the conclusion that financial institutions remained prudent lenders even as they expanded their loans to home buyers, regardless of whether they had strict limits on real estate like national banks or minimal regulations like state banks. They had adequate collateral and capital to meet substantial potential defaults; and their shareholders, generally subject to double liability, may have monitored management more carefully. This picture stands in stark contrast to the experience of recent years when financial institutions became increasingly leveraged with more and more risky assets both on and off their balance sheets.

\subsection{State Deposit Insurance}

In the 1920s, the federal government provided few incentives to banks to take more risk, though the Federal Reserve's policy of reducing seasonal interest rate volatility appears to have induced additional risk taking and may have expanded real estate lending. Yet, compared to today when depositors are provided with high levels of explicit deposit guarantees and implicit 100 percent insurance from the "too big to fail" doctrine, broad government protections that create risk-taking incentives were absent. There was no federal deposit insurance to induce morally hazardous behavior by banks. Several states had experimented with deposit insurance for state banks after the panic of 1907. All were very rural states, and most bank failures in the 
1920s (79 percent) were in rural areas (Alston, Grove, and Wheelock 1994), while the banks most deeply involved in the housing boom of the twenties were not insured and were located primarily in urban areas.

However, these state experiments provide considerable evidence that deposit insurance may create a dangerous moral hazard. Using individual bank data for Kansas in the twenties, where state deposit insurance was voluntary, Wheelock (1992a) found that the balance sheets of insured banks exhibited greater risk taking, and that insured banks were more likely to fail than noninsured banks. By the simplest test, the capital-to-asset ratio was significantly lower for insured banks compared to uninsured banks, averaging 11 percent and 14 percent respectively. ${ }^{33}$ County-level data revealed that deposit insurance did not prevent bank failures in counties suffering from the greatest agricultural distress in the 1920s (Wheelock 1992a). More generally, state-level banking data suggests that state deposit insurance induced rural banks to increase risk as their net worth declined (Alston, Grove, and Wheelock 1994).

Contemporary analysts and even many legislators understood the problems generated by deposit insurance and generally assessed these experiments as failures. ${ }^{34}$ In contrast to today, where deposit insurance is viewed as politically sacrosanct, the none-too-successful state experience may have quashed enthusiasm for deposit insurance at the federal level until the Great Depression. While deposit insurance induced rural banks to expand and take risks and added to their probability of failure, it was absent for most urban banks focused on residential lending, playing little role in the real estate booms of the 1920s.

\subsection{The Role of Bank Supervision}

For the recent real estate boom, there are claims that bank supervision failed either to detect the deterioration of banks' balance sheets and/or showed forbearance in disciplining excessively risky institutions (National Commission 2011). Similarly, in the 1920s, financial institutions may also have taken more risk and expanded their real estate lending if the examination and supervision policies of the Office of the Comptroller of the Currency (OCC), the Federal Reserve, and the state bank regulators had weakened. Although there is scant secondary literature on the general quality of bank supervision in the 1920s, there are allegations that it failed in certain

33. These ratios are calculated from Wheelock (1992a, table 1).

34. Following the panic of 1907, seven states (North Dakota, South Dakota, Kansas, Nebraska, Oklahoma, Texas, and Mississippi) established deposit guarantee funds. Several produced extraordinary examples of unchecked morally hazardous behavior. For the debates on deposit insurance see Flood (1991) and Calomiris and White (1994). The state-operated deposit insurance systems are analyzed in White (1983), Calomiris (1990), and Wheelock (1992a). 
boom regions. These charges and supervisory performance can be partly evaluated with data from the Office of the Comptroller of the Currency, which was responsible for supervision of national banks. ${ }^{35}$

Supervision of financial institutions can be evaluated by its three basic components - disclosure, examination, and enforcement. First, disclosure aims at inducing banks to provide uniform information to the public that will allow depositors and other creditors to determine the safety of the bank. In the pre-deposit insurance era, disclosure was regarded as essential to keep the public informed. In 1869, Congress required the Comptroller of the Currency to call for a minimum of five reports of condition, or "call reports," with three surprise dates of the comptroller's choosing. The random choice of dates was aimed at preventing window dressing of data. However, banks generally dislike disclosing information because they claim that it reveals proprietary information. Thus, the second supervisory activity - examination-permits government officials to perform a more detailed and confidential examination of the bank's condition, in addition to determining whether it is meeting regulatory requirements. Last, if a bank is deficient, the bank supervisors may impose some penalty to bring the bank back into compliance. In the 1920s, if a bank's capital was discovered to be impaired and stockholders' contributions, sales of stock, or unassisted mergers failed to remedy the deficiency, the examiners would order the board of directors to close the bank (Jones 1940). Very generally, comptrollers repeatedly stressed that their job was to reinforce the operation of the market by ensuring disclosure and promptly closing insolvent institutions (Robertson 1968).

The 1920s witnessed a change in the quality of disclosure. The Federal Reserve Act of 1913 gave the Board of Governors the power to demand reports and examine member banks (Kirn 1945), but the OCC initially carried out examination of state member banks in addition to national banks. When Comptroller Williams requested a sixth report and more detailed information, he provoked a flood of complaints from the banks. As a consequence of this uproar and the inequality between the requirements imposed on national and state member banks, the 1917 amendment to the Federal Reserve Act ordered state member banks to make their reports of condition to their Federal Reserve Bank. Additionally, the minimum number of call reports was reduced to three, rather than the five required of national banks. Furthermore, the power to set call dates was transferred to the board.

This regime shift was not complete until Williams left office in late 1921, beginning a weakening of the disclosure process. In 1922, the number of call reports fell back to five; in 1923, it dropped to four and remained at that level for 1924 and 1925. There is no comment about this change in the

35. For the Great Depression, Mitchener $(2005,2007)$ has studied the effectiveness of state agencies in preventing bank failures. He found that when state supervisors were granted longer terms of office and sole chartering authority they misused this authority, while sole authority to liquidate banks brought about quicker resolutions with less spillover to other institutions. 
Annual Reports of the Comptroller of the Currency or the Federal Reserve Board or in the Federal Reserve Bulletin, but in the boom year of 1926, there were only three call reports - one for April 12, June 30, and December 3. In 1927, the board called for four reports, a number it adhered to in subsequent years. The reduction in reports suggests that the Fed was under pressure from the national banks to reduce their reporting and put them on a par with state member banks. If so, this is an example of the "competition in laxity" between state and federal regulators that had led to a reduction of capital and reserve requirements in the late nineteenth and early twentieth centuries (White 1983) and that, combined with "regulatory arbitrage," continues to bedevil contemporary American regulators. Alternatively, the Fed may have been alarmed by the condition of some banks, given that real estate values had begun to decline. The decision to skip the October 1926 call may have been made to give banks time to raise capital or make other adjustments.

Conversely, the record of bank examination reveals no such obvious deterioration and may have improved in some dimensions. All national banks had been examined twice yearly since 1898 (Kirn 1945). These examinations were intended to be unanticipated in order to provide the comptroller with a true picture of the condition of national banks and their compliance with regulations. It was well known that this surprise element had been undermined by the incentives from the compensation of examiners. Paid a fixed fee for each bank examined, officials minimized travel costs. The appearance of an examiner at one bank heralded an imminent visit at nearby banks. The new Federal Reserve regime improved examination by eliminating this incentive. Examiners were put on a salary and their expenses were paid. In addition, they were provided with assistants to handle the minor details of examination. (OCC 1919). Although the comptroller was initially responsible for examining state member banks, the 1917 amendment transferred this power to the Federal Reserve banks that organized their own examination departments. ${ }^{36}$ The OCC reorganized its examiners in 1915 by Federal Reserve District and established a chief national bank examiner with responsibility for all examiners in the district. The resources available to the comptroller under this new regime remained roughly steady. Between 1923 and 1929, revenue, primarily from examination fees, varied between $\$ 2.1$ and $\$ 2.4$ million. ${ }^{37}$ To examine the roughly eight thousand banks, the OCC employed only slightly more than two hundred examiners. Overall, the supervisory regime had a relatively light hand and relied heavily on the discipline of the market. While the number of banks per examiner was stable, real assets per examiner increased by 20 percent, which must have added to the examiners' workload, with no compensating increase in resources for

36. State banks complained about bearing the cost of state examinations in addition to those of the Fed, though the board could accept state examinations in lieu of additional federal ones (Kirn 1945, 164).

37. Office of the Comptroller of the Currency, Annual Reports, 1922-1929. 
the agency. If there was a problem, it was that the agency was revenue constrained and could not readily respond, given its fee structure.

Although there was a nationwide real estate boom, Florida was singled out for reckless banking and a failure of bank supervision (Vickers 1994; Frazer and Guthrie 1995). Entry into Florida banking had been constrained by the refusal of the OCC to approve any new national charters between 1907 and 1921. This changed when the banker-developers Wesley D. Manley and James R. Anthony Jr. persuaded Florida's Senator Duncan U. Fletcher to intervene with the comptroller on their behalf. By merger and de novo charter, they assembled a chain of sixty-one national and state banks by 1925. At the state level, Anthony developed close ties to Florida comptroller Ernest Amos, who offered charters, easy supervision, and control of receiverships in exchange for campaign funds and unsecured bank loans for real estate speculation. Insider lending was widespread and often exceeded legal limits. State examiners winked at these activities, and the public was largely kept in the dark. ${ }^{38}$

This closely intertwined and sometimes corrupt relationship between developers, bankers, and regulators kept failed banks open. The Florida State comptroller's 1926 report concealed the deteriorating condition of the banks - notably the insolvent Palm Beach Bank and Trust Company. At the federal level, the national bank examiner found the Palm Beach National Bank to be insolvent in February 1926, but his superiors prevented its closure. At the same time, the Federal Reserve Bank of Atlanta, whose governor, M. B. Wellborn, was an intimate of Manley and Anthony, made a loan to this bank equal to 87 percent of its capital. News that one of the Manley-Anthony development companies was insolvent triggered a run on its allied banks on June 21, 1926. The bank's closure sparked a general run on the bank chains in both Florida and Georgia, with widespread failures. The regional interest rate shock to the South uncovered by Landon-Lane and Rockoff (2007) was no doubt a consequence of this disaster. Yet the panic did not spread to all Florida or all regional banks, as depositors appear to have been sufficiently well informed to distinguish between the solvent and insolvent institutions.

Overall, the OCC, which most contemporary observers conceded was the best bank regulatory agency, did not noticeably respond to the real estate boom. It garnered no additional resources, nor did it redirect its existing funds or manpower to increase supervision of rapidly expanding banking systems in hot regional markets. It may even have mildly encouraged the boom by easing entry into banking. More seriously, state supervisors such

38. In contrast to the abysmal performance by state regulators, the Atlanta District of the OCC did not reduce its oversight. Florida had one examiner, stationed in Jacksonville who later moved to Lakeland, perhaps reflecting the shift of population and activity southward. Yet, the OCC faced the same problem in the Atlanta District and Florida as it did nationally as the size of banks was quickly increasing 
as those in Florida may have been co-opted by land promoters and allowed the creation of house-of-cards banking chains. Crucially, however, these failures did not imperil the whole of the banking system, which remained sufficiently well capitalized to withstand the fall in the value of real estate.

\subsection{Foreclosures and Home Ownership}

While there was no banking collapse in the twenties, the effects of the post-1926 collapse of the housing market show up in the foreclosure data. Unfortunately, there are no national foreclosure statistics before 1926. The only available series that covers the 1920s is the foreclosures completed during the year per thousand nonfarm real estate mortgages for 1926 to 1941, displayed in figure 4.15. After the real estate market began to decline in 1926, foreclosures steadily increased every year through the shock of the Great Depression. However, there was an extraordinary rescue of the mortgage market by the federal government during the Depression, which included the creation of the Home Owners' Loan Corporation in 1933 (Courtemanche and Snowden 2011). As a consequence, foreclosures during the Depression years may be misleadingly low. Nevertheless, the foreclosure rate in the mid1920 s is much higher than the early post-World War II period when the series briefly was continued from 1950 to 1968.

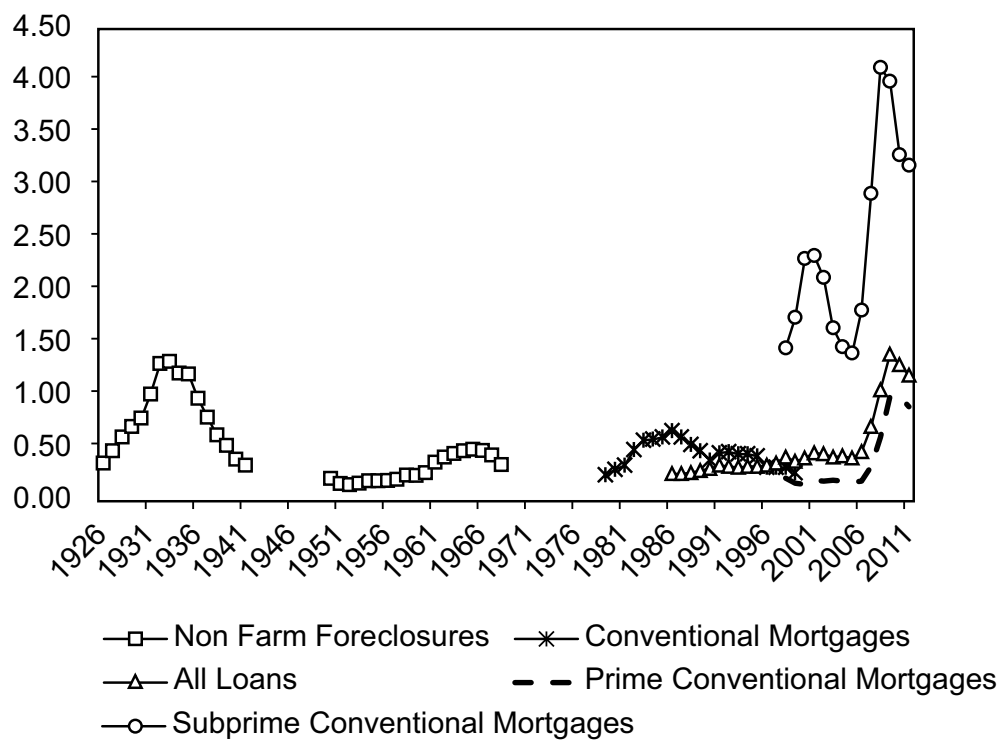

Fig. 4.15 Foreclosures (percent), 1926-2011

Sources: Carter et al. (2006, series Dc1257, Dc1283); US Department of Housing and Urban Development $(2008,2011)$. 
For later years, a straightforward comparison is difficult because the nonfarm foreclosure series was discontinued and replaced with a series that records the number of foreclosures begun during a year, instead of the number completed. Thus, the series are only roughly similar. The creation of Federal Housing Authority (FHA) and Veterans Administration (VA) insurance programs complicate comparisons further. The series "All Loans" includes foreclosures on "Conventional," VA, and FHA mortgages. "Conventional Prime" and "Subprime Conventional" foreclosures are a subcategory of conventional foreclosures. Attempting to hold the type of loan constant for comparisons, one should probably exclude subprime mortgages because they expanded the mortgage market and increased the risk of foreclosure. In spite of all of these qualifications, only prime conventional mortgages foreclosure rates remained at midcentury levels until the crisis hit in 2008. All rates suggest that rates were relatively high through the 1980s and 1990s, taking off to Great Depression levels beginning in 2007. The similarity of all but subprime foreclosure rates after 1926 and after 2008 points to a key difference: who held troubled mortgages. Even though housing prices sagged and foreclosure rates doubled between 1926 and 1929, 1920s banks, unlike their early-twenty-first-century descendants, were saddled with only modest losses from their small mortgage portfolios that were manageable with low leverage. However, this comparison does raise the broad question why rates may have been relatively high, even on conventional mortgages, in the prosperous and tranquil last decade of the twentieth century and then soared on all categories.

Part of the answer certainly lies in the huge increase in home ownership and government-induced changes in mortgage characteristics that occurred in the second half of the twentieth century. Compared to post-World War II mortgages, the typically short-term, high loan-to-value ratio mortgages issued during the 1920s were less likely to produce large losses, ensuring that financial intermediaries could survive a drop of 10 or 20 percent in the value of the collateral. The other factor was the ability of households to sustain their mortgage payments. Compared to today, the mortgage market in the twenties provided funds to a very different pool of households. Figure 4.16 reports the home ownership rates. Unfortunately, until 1969 this data is only available every ten years from the census. Nevertheless, the graph reveals a striking post-World War II jump.

At the beginning of the twentieth century, 47 percent of households owned their own homes. This proportion drifted down slightly in the next two decades then rose during the housing boom of the twenties, only to drop sharply during the Depression. Yet these movements are dwarfed by the post-World War II rise, assisted by federal policies such as the establishment of the Federal Housing Administration (FHA), Fannie Mae, and Freddie Mac. By 1970, a plateau was reached with nearly 65 percent of the households owning their own homes. The second secular rise began in the 


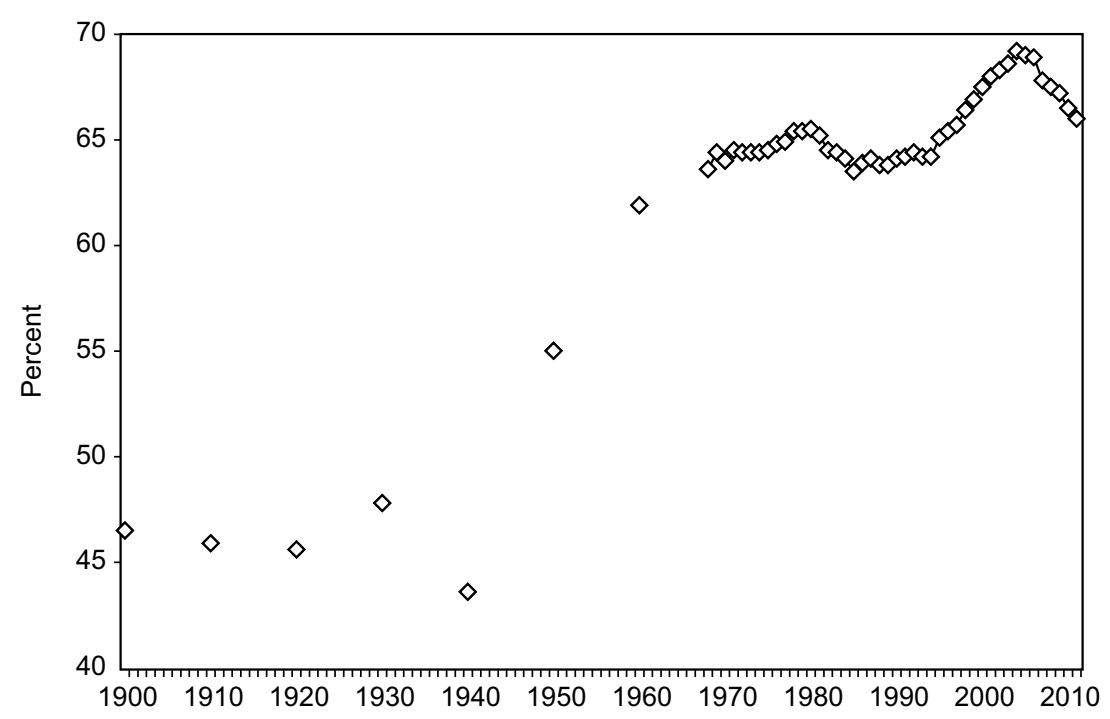

Fig. 4.16 Home ownership rates, 1900-2011

Sources: Carter et al. (2006, series Dc781 and Dc761); US Census Bureau, Housing Vacancies and Homeownership (2008, table 14, www.census.gov).

1990s, when new federal efforts to make mortgages attractive to previously ineligible households took effect. Unfortunately, the current crisis revealed that many individuals who obtained mortgages had a minimal capacity to make mortgage payments and a high propensity to default. The lower levels of home ownership in the 1920s suggest that higher risk households did not have access to mortgages and did not participate in the boom. This difference appears to be borne out by the higher levels of foreclosures in the late twentieth century, levels that even in prosperous times greatly exceeded foreclosure levels during the 1920s and 1930s.

\subsection{The Boom and Bust in Retrospect}

In the search for explanations of the joint real estate-banking collapse of 2007 to 2008, a comparison with the 1920s is instructive. Even though the dimensions of the residential housing bubbles were similar, the bust in the twenties did not undermine the banking system or derail the economy. Many of the alleged causes of the recent disaster were also in evidence in the 1920s. There appears to have been an easing of monetary policy by the Federal Reserve, an equivalent of the "Greenspan put," and unresponsive or complacent bank supervision at the federal and the state levels. Bank lending standards declined, and the high risk in the booming securitized mortgage industry went undetected by the rating agencies or by an optimistic public 
lulled by use of opaque securitized instruments. All of these factors certainly contributed to the boom, but they were not enough to undermine the banking system.

What was absent in the 1920s were policies that induced banks to take increased risks. In the twenties, there was no federal intervention in mortgage markets. Far more households rented; and the boom only increased home ownership from approximately 45 to 50 percent of households, while the early twenty-first century boom drove up home ownership from 65 to 69 percent. Because it provided new mortgages to home owners with significantly lower incomes and wealth, many features of the recent boom were more extreme, even if they are not easily quantifiable. While contemporaries in the 1920s may have decried buildings and loan associations' innovations that permitted mortgagors' effective down payments of only 20 percent, these terms appear conservative compared to zero down payment loans that characterized some mortgages in the early twenty-first century. Similarly, while securitized mortgages in the twenties obscured some of the risk present in a pool of mortgages, there was more risk to be hidden in subprime loans and hence the greater degree of complexity of more recent securitized products. This higher level of risk is apparent in the aggregate foreclosure rates of recent stable economic times that often exceeded the foreclosure rates of the post-1926 bust and the Great Depression.

Furthermore, in the 1920s, bankers were not tempted by moral hazard from deposit insurance or the too big to fail policy to take more risk on or off their balance sheets. In fact, the general imposition of double liability on bank stock may have induced bank managers, subjected to greater monitoring by shareholders, to reduce risk taking. However, this is not to say that the regulations governing the banking system of the 1920s made it particularly resilient to shocks. The dominance of small, undiversified single-office banks translated shocks from the post-World War I collapse in agricultural prices and the Great Depression into waves of bank failures. ${ }^{39}$

Yet, faced with incentives set by the market and government policies, banks and other financial institutions in the 1920s remained prudent, modestly lowering lending standards and increasing their holdings of mortgages. When the bust came, large losses did not accrue to them; and the most risky securitized mortgages were held by investors, not leveraged financial institutions. Banks and other intermediaries that had participated in the boom survived until the Great Depression unexpectedly hammered the banking system and home owners, causing the housing boom and bust of the 1920s to fade from sight.

39. For discussions of these issues see, for example, White (1983), Wheelock (1992a, 1992b), and Mitchener (2007). 


\section{References}

Alston, Lee J., Wayne A. Grove, and David C. Wheelock. 1994. "Why Do Banks Fail? Evidence from the 1920s." Explorations in Economic History 31:409-31.

Balke, Nathan S., and Robert J. Gordon. 1986. "Appendix B Historical Data." In The American Business Cycle: Continuity and Change, edited by Robert J. Gordon, 781-850. Chicago: University of Chicago Press.

Barsky, Robert, N. Gregory Mankiw, Jeffrey Miron, and David Weil. 1988. "The Worldwide Change in the Behavior of Interest Rates and Prices in 1914." European Economic Review 32 (5): 1123-54.

Berger, Allen N., Richard J. Herring, and Giorgio P. Szëgo. 1995. "The Role of Capital in Financial Institutions." Journal of Banking and Finance 19:393-430.

Board of Governors of the Federal Reserve System. 1943. Banking and Monetary Statistics, 1914-1943. Washington, DC: BOGFRS.

Calomiris, Charles W. 1990. "Is Deposit Insurance Necessary?" Journal of Economic History 50:283-95.

Calomiris, Charles W., and Eugene N. White. 1994. "The Origins of Federal Deposit Insurance." In The Regulated Economy: A Historical Approach to Political Economy, edited by Claudia Goldin and Gary D. Libecap, 145-88. Chicago: University of Chicago Press.

Caporale, Tony, and Barbara McKiernan. 1998. "Interest Rate Uncertainly and the Founding of the Federal Reserve." Journal of Economic History 58 (4): 1110-7.

Carter, Susan B., Scott S. Gartner, Michael R. Haines, Alan L. Olmstead, Richard Sutch, and Gavin Wright, eds. 2006. Historical Statistics of the United States: Earliest Times to the Present. Millennial edition. Cambridge: Cambridge University Press.

Clark, Truman. 1986. "Interest Rate Seasonals and the Federal Reserve." Journal of Political Economy 94 (1): 76-125.

Courtemanche, Charles, and Kenneth A. Snowden. 2011. "Repairing a Mortgage Crisis: HOLC Lending and Its Impact on Local Housing Markets." Journal of Economic History 71 (2): 307-37.

Coval, Joshua, Jakub Jurek, and Erik Stafford. 2009. "The Economics of Structured Finance." Journal of Economic Perspectives 23 (1): 3-26.

Crockett, Andrew, Trevor Harris, Frederic S. Mishkin, and Eugene N. White. 2003. Conflicts of Interest in the Financial Services Industry: What Should We Do About Them? Geneva: International Center for Monetary and Banking Studies.

Economic Report of the President. 2009. Washington, DC: Government Printing Office.

Edelstein, Michael. 2000. "War and the American Economy in the Twentieth Century." In The Cambridge Economic History of the United States: The Twentieth Century, vol. III, edited by Stanley L. Engerman and Robert E. Gallman, 329-405. Cambridge: Cambridge University Press.

Federal Reserve Board. 1915-1929. Annual Reports. Washington, DC: Government Printing Office.

Field, Alexander J. 1992. "Uncontrolled Land Development and the Duration of the Depression in the United States." Journal of Economic History 52 (4): 785-805.

Fishe, Raymond P. H., and Mark Wohar. 1990. "The Adjustment of Expectations to a Change in Regime: Comment." American Economic Review 80 (4): 968-76.

Fisher, Ernest M. 1951. Urban Real Estate Markets: Characteristics and Financing. New York: National Bureau of Economic Research.

Flood, Mark D. 1991. "The Great Deposit Insurance Debate." Federal Reserve Bank of St. Louis Review 74:51-77. 
Frazer, William, and John J. Guthrie Jr. 1995. The Florida Land Boom: Speculation, Money and the Banks. Westport, CT: Quorum Books.

Friedman, Milton, and Anna J. Schwartz. 1963. A Monetary History of the United States 1867-1960. Princeton, NJ: Princeton University Press.

Galbraith, John Kenneth. 1988[1954]. The Great Crash: 1929. Boston: Houghton Mifflin Company.

Glaeser, Edward L., Joseph Gyourko, and Raven Saks. 2005. "Why Have Housing Prices Gone Up?” NBER Working Paper no. 11129, Cambridge, MA.

Goetzmann, William N., and Frank Newman. 2010. "Securitization in the 1920s." NBER Working Paper no. 15650, Cambridge, MA.

Goldsmith, Raymond W. 1958. Financial Intermediaries in the American Economy since 1900. Princeton, NJ: Princeton University Press.

Gorton, Gary. 2008. “The Subprime Panic.” NBER Working Paper no. 14398, Cambridge, MA.

Greenspan, Alan. 2009. "The Fed Didn't Cause the Housing Bubble." Wall Street Journal, March 11.

Grebler, Leo, David M. Blank, and Louis Winnick. 1956. Capital Formation in Residential Real Estate: Trends and Prospects. Princeton, NJ: Princeton University Press.

Grossman, Richard S. 2001. "Double Liability and Bank Risk Taking." Journal of Money, Credit and Banking 33 (2, part 1): 143-59.

—. 2007. "Fear and Greed: The Evolution of Double Liability in American Banking, 1865-1930." Explorations in Economic History 44:59-80.

Hoyt, Homer. 1933. One Hundred Years of Land Values in Chicago. New York: Arno Press.

Johnson, Ernest A. 1936. "The Record of Long-Term Real Estate Securities.” Journal of Land and Public Utilities Economics 12:44-8.

Joint Center for Housing Studies of Harvard University. 2008. The State of the Nation's Housing. Cambridge, MA: Fellow of Harvard College.

Jones, Homer. 1940. "An Appraisal of the Rules and Procedures of Bank Supervision, 1929-1939." Journal of Political Economy 48 (2): 183-98.

Kindleberger, Charles P. 1978. Manias, Panics, and Crashes: A History of Financial Crises._New York: Basic Books.

Kirn, Brian A. 1945. Financial Reports of American Commercial Banks. Washington, DC: The Catholic University of American Press.

Koester, Genevieve. 1939. "Chicago Real Estate Bonds, 1919-1938: I Corporate History." Journal of Land and Public Utilities Economics 15:49-58.

Kool, Clemens J. M. 1995. "War Finance and Interest Rate Targeting: Regime Changes in 1914-1918." Explorations in Economic History 32 (3): 365-82.

Kroszner, Randall S., and Raghuram G. Rajan. 1994. "Is the Glass-Steagall Act Justified? A Study of the U.S. Experience with Universal Banking Before 1933." American Economic Review 84 (4): 810-32.

1997. "Organization, Structure, and Credibility: Evidence from Commercial Bank Securities Activities before the Glass-Steagall Act." Journal of Monetary Economics 39 (3): 475-516.

Landon-Lane, John, and Hugh Rockoff. 2007. "The Origin and Diffusion of Shocks to Regiona Interest Rates in the United States, 1880-2002." Explorations in Economic History 44 (3): 487-500.

Macey, Jonathan R., and Geoffrey P. Miller. 1992. "Double Liability of Bank Shareholders: History and Implications." Wake Forest Law Review 27:31-62.

Mankiw, N. Gregory, Jeffrey A. Miron, and David N. Weil. 1987. "The Adjustment of Expectations to a Change in Regime: A Study of the Founding of the Federal Reserve." American Economic Review 77 (3): 358-74. 
Mayer, Christopher, Karen Pence, and Shane M. Sherlund. 2009. "The Rise in Mortgage Defaults.” Journal of Economic Perspectives 23 (1): 27-50.

Meltzer, Allan H. 2003. A History of the Federal Reserve, vol. 1, 1913-1952. Chicago: University of Chicago Press.

Miller, Marcus, Paul Weller, and Lei Zhang. 2002. "Moral Hazard and the U.S. Stock Market: Analyzing the 'Greenspan Put."' Economic Journal 112 (478): 171-86.

Miron, Jeffrey A. 1986. "Financial Panics, the Seasonality of the Nominal Interest Rate and the Founding of the Fed." American Economic Review 76 (1): 125-40.

Mitchener, Kris James. 2005. "Bank Supervision, Regulation, and Instability During the Great Depression.” Journal of Economic History 65 (1): 152-85. . 2007. "Are Prudential Supervision and Regulation Pillars of Financial Stability? Evidence from the Great Depression." Journal of Law and Economics 50 (2): 273-302.

Morton, J. E. 1956. Urban Mortgage Lending. Princeton, NJ: Princeton University Press.

National Commission on the Causes of the Financial and Economic Crisis in the United States. 2011. The Financial Crisis Inquiry Report. Washington, DC: Government Printing Office.

Nicholas, Tom, and Anna Scherbina. 2011. "Real Estate Prices during the Roaring Twenties and the Great Depression." UC Davis Graduate School of Management Research Paper no. 18-09.

Office of the Comptroller of the Currency. 1918-1929. Annual Reports. Washington, DC: OCC.

Office of Federal Housing Enterprise Oversight. 2008. "Revisiting the Differences between the OFHEO and S\&P/Case-Shiller House Price Indices: New Explanations." January.

Orphanides, Athanasios. 2003. "Historical Monetary Policy Analysis and the Taylor Rule." Journal of Monetary Economics 50 (5): 983-1022.

Pozsar, Zoltan, Tobias Adrian, Adam Ashcraft, and Hayley Boesky. 2012. "Shadow Banking." Federal Reserve Bank of New York Staff Report no. 458. February.

Puri, Manju. 1994. "The Long-Term Default Performance of Bank Underwritten Security Issues." Journal of Banking and Finance 18 (2): 397-418.

Rappoport, Peter, and Eugene N. White. 1994. "Was the Crash of 1929 Expected?" American Economic Review 84 (1): 271-81.

Robertson, Ross M. 1968. The Comptroller and Bank Supervision: A Historical Appraisal. Washington, DC: Office of the Comptroller of the Currency.

Rockoff, Hugh. 2012. America's Economic Way of War: War and the U.S. Economy from the Spanish American War to the Persian Gulf War. Cambridge: Cambridge University Press.

Sanati, Cyrus. 2009. "10 Years Later, Looking at Repeal of Glass-Steagall.” New York Times, November 12.

Schwartz, Anna J. 1992. "The Misuse of the Fed's Discount Window." Federal Reserve Bank of St. Louis Review 74 (5): 58-69.

Shiller, Robert J. 2000. Irrational Exuberance, 1st ed. Princeton, NJ: Princeton University Press.

Simpson, Herbert D. 1933. "Real Estate Speculation and the Depression." American Economic Review 23 (1): 163-71.

Snowden, Kenneth A. 1995. "Mortgage Securitization in the United States: Twentieth Century Developments in Historical Perspective." In Anglo-American Financial Systems, Michael D. Bordo and Richard Sylla, 261-98. New York: Irwin.

- 2010. "The Anatomy of a Residential Mortgage Crisis: A Look Back to the 1930s.” NBER Working Paper no. 16244, Cambridge, MA. 
Taylor, John B. 1993. "Discretion Versus Policy Rules in Practice." CarnegieRochester Conference Series on Public Policy 39:195-214. 1999. "A Historical Analysis of Monetary Policy Rules." In Monetary Policy Rules, edited by John B. Taylor, 319-48. Chicago: University of Chicago Press. 2007. "Housing and Monetary Policy." Symposium on Housing, Housing Finance and Monetary Policy, Jackson Hole, Wyoming, September. Proceedings, Federal Reserve Bank of Kansas City, 463-76. 2009. "The Financial Crisis and the Policy Responses: An Empirical Analysis of What Went Wrong." NBER Working Paper no. 14631, Cambridge, MA.

Temin, Peter. 1976. Did Monetary Forces Cause the Great Depression? New York: W.W. Norton \& Company.

U.S. Census Bureau. www.census.gov.

Vickers, Raymond B. 1994. Panic in Paradise: Florida's Banking Crash of 1926. Tuscaloosa: University of Alabama Press.

Welldon, Samuel A. 1909. Digest of State Banking Statutes. Washington, DC: National Monetary Commission.

Wheelock, David C. 1991. The Strategy and Consistency of Federal Reserve Monetary Policy, 1924-1933. Cambridge: Cambridge University Press.

- 1992a. "Deposit Insurance and Bank Failures: New Evidence from the 1920s.” Economic Inquiry 30:530-43. 1992b. "Monetary Policy in the Great Depression: What the Fed Did and Why." Federal Reserve Bank of St. Louis Review March/April:3-28.

White, Eugene N. 1983. The Regulation and Reform of the American Banking System 1900-1929. Princeton, NJ: Princeton University Press.

1986. "Before the Glass-Steagall Act: An Analysis of the Investment Banking Activities of National Banks." Explorations in Economic History 23 (1): 33-55.

Wilson, J. Holton, and Barry Keating. 2002. Business Forecasting. Boston: McGraw Hill.

Wicker, Elmus R. 1966. Federal Reserve Monetary Policy, 1917-1933. New York: Random House.

Wiggers, Tyler, and Adam B. Ashcraft. 2012. "Defaults and Losses on Commercial Real Estate Bonds during the Great Depression Era." Federal Reserve Bank of New York Staff Report No. 544, February. 